\title{
Excessive Risk-taking and the Structure of Executive Compensation ${ }^{1}$
}

\author{
Vasiliki Athanasakou \\ Dept. of Accounting \\ London School of Economics \\ V.Athanasakou@lse.ac.uk \\ Lisa Goh \\ Dept. of Accounting \\ London School of Economics \\ L.Goh@lse.ac.uk \\ Daniel Ferreira \\ Dept. of Finance \\ London School of Economics \\ D.Ferreira@lse.ac.uk
}

This version: January 2011

JEL Classifications: G30, G32, J33, M41, M52

\footnotetext{
${ }^{1}$ We thank colleagues from the London School of Economics and Political Science for their useful comments.
} 


\begin{abstract}
We examine changes to executive compensation contracts in the presence of excessive risk-taking. Prior research has linked option-based compensation with risktaking and aggressive financial reporting, which is observed following earnings restatements. We further this literature by examining excessive risk-taking, using measures of CEOs' continued holding of exercisable options and high levels of R\&D. Using a large sample of firms from 1994-2008, we find that these characteristics have a negative association with future option grants. However, we find that the ability of the compensation committee to detect and respond to excessive risk-taking is mitigated in the presence of aggressive financial reporting.
\end{abstract}




\section{Excessive Risk-taking and the Structure of Executive Compensation}

\section{Introduction}

The recent financial crisis along with the rush of corporate failures and exposed accounting irregularities have drawn attention to managers' excessive risk-taking and the role of compensation contracts in promoting such behavior and creating incentives to manage short-run performance at the expense of long-term value. This series of events suggests that compensation contracts previously in place were not optimally designed to mitigate agency problems. Equity-based incentives in these contracts were like "throwing gasoline on a fire", fuelling risky investment and financial reporting decisions to keep the stock prices high and rising (Jensen, 2005, 14; Efendi et al., 2007). In the aftermath of these events, the role of compensation contracts as a monitoring device becomes crucial. In this paper, we examine whether excessive risk-taking is taken into consideration in the design of Chief Executive Officer (CEO) compensation contracts, and if aggressive reporting affects the design and efficacy of the contracts.

Prior literature has found that compensation committees reduce the size of option grants following earnings restatements (Cheng and Farber, 2008), considering evidence that large option holdings may result in manager overincentivization (Efendi et al., 2007). In the spirit of Core and Guay (1999), this suggests that compensation committees respond and move towards restoring optimal contracting when there is clear evidence of misalignment, i.e. in this case, when aggressive reporting becomes publicly known. However, since earnings restatements occur fairly infrequently, it is difficult to generalize this to firms that have not demonstrated significant failures in reporting. Also, restatements are by definition retrospective, and for some parties, incentive re-alignment or corrective action is "too little, too late".

Core and Guay (1999) suggest that sub-optimal equity incentives play a role in the design of subsequent equity grants, however, research has in large part focused on other factors affecting the structure of compensation, e.g. director characteristics, investment opportunities, corporate governance, the information environment, and on the outcomes of compensation design, such as firm performance, investment decisions, risk, etc. There is limited research on feedback effects from these outcomes into compensation design, for example, the effect of riskier investment decisions (Coles et al., 2006), and of earnings restatements (Cheng and Farber, 2008) in the structure of compensation contracts. 
Prior literature has identified a link between stock options and risky investments or risk-taking (Agrawal and Mandelker, 1987; Rajgopal and Shevlin, 2002; Ju et al., 2003; Cohen et al., 2007), and the probability of default (Balachandran et al., 2010). Over time, these equity incentives may become suboptimal due to changes in firm and director characteristics, and changes in the equity portfolios (Core and Guay, 1999). In this paper, we examine whether boards respond to evidence of excessive risk-taking by reducing future stock option grants to their CEOs. Our approach differs in that we model compensation structure as a function of prior risk-taking, which is observed by the compensation committee. In response to prior anecdotal and empirical evidence on the damaging effects of aggressive reporting (Jensen, 2005; Efendi et al., 2007), we also investigate how aggressive reporting affects the dynamic adjustment of the compensation contracts to excessive risk-taking. The ability of compensation committees to respond to excessive risk-taking depends on their ability to detect it and to judge that it is excessive. It is possible that aggressive reporting hinders this ability by masking the level of risk and the failure of previous risky decisions and leading to a miscalibration of what is "risky" on the part of the compensation committee.

Our measures of excessive risk-taking are derived from observed CEOs' holdings of exercisable options that are deep in-the-money (Malmendier and Tate, 2005; Campbell et al., 2010), and overinvestment in $R \& D$, both of which imply higher risk for the firm and its shareholders. We examine whether compensation committees respond to this evidence of excessive risk-taking by reducing stock option grants in the following period. We find that firms with CEOs that hold exercisable options deep in-the-money and firms that report abnormally high $R \& D$ expenses respond in the subsequent period by reducing the number of stock options granted to CEOs, consistent with an effort to reduce risk incentives.

We then investigate the role of aggressive reporting. To identify firms engaging in aggressive reporting, we focus on firms reporting abnormally high performance adjusted abnormal accruals (Kothari et al., 2005). Our results show that stock option grants are not revised in response to aggressive reporting. Moreover, evidence of a reduction in future stock option grants in response to excessive risk-taking is attenuated for firms engaging in aggressive reporting, i.e. firms belonging to the top quintile of discretionary accruals, suggesting that compensation committees fail to detect aggressive reporting, or that aggressive reporting successfully shifts the risk appetite of the compensation committee. 
We contribute to the literature on the structure of CEO compensation contracts, establishing an association between excessive risk-taking and revisions in compensation contracts. First, we extend work of Burns and Kedia (2006), Efendi et al. (2007), and Cheng and Farber (2008) on stock options, earnings restatements and revisions in the compensation contract. We provide evidence that compensation committees are on average able to detect and react to excessive risk-taking created by over-incentives from stock options and revise their grants in light of evidence on excessive risk-taking. Second, we provide evidence on the damaging effects of earnings management. Consistent with evidence that compensation committees correct equity incentives only after the problem of aggressive financial reporting becomes publicly known, we find that earnings management is indeed not factored into revisions of option-based compensation. Last, we show that aggressive reporting hinders the detection and response to excessive risk-taking, and therefore deters efficiency in setting of an optimal contract.

The results of our study have implications for the design of compensation contracts. They suggest that firms are, on average, able to detect excessive risk-taking associated with overincentivization and move towards optimality, on a dynamic basis. However, compensation committees need to look more closely at accounting choices, as their ability to detect risk-taking is hindered by aggressive reporting.

The rest of the paper is organized as follows. Section 2 reviews literature on determinants of compensation contract, their outcomes, and develops our hypotheses. Section 3 discusses our measures of excessive risk-taking, aggressive reporting, and our empirical model. Section 4 describes our sample and data. Section 5 presents our findings, and Section 6 concludes.

\section{Literature Review}

Our key research hypotheses focus on excessive risk-taking as a deviation from optimal compensation contracts. Prior literature on the design of compensation contracts has shown that compensation contracts can be affected by a number of firm and director characteristics. Another strand of literature examines the outcomes of compensation contracts, showing that they can create incentives leading to optimal or sub-optimal outcomes at the firm-level. We review both strands of the literature and focus on how a sub-optimal outcome, i.e. excessive risk-taking, can be factored in the design of the compensation contracts. 


\subsection{Determinants of executive compensation contracts}

Prior research has documented a number of economic determinants of executive compensation. The most well-documented economic determinant is firm size (Murphy, 1999), with other factors such as firm performance, investment opportunities (Lambert and Larcker, 1987; Smith and Watts, 1992; Gaver and Gaver, 1993; Baber et al., 1996; Bryan et al., 2000), liquidity constraints (Yermack, 1995), operational complexity (Bushman et al., 2004), and financial policies (Agrawal and Mandelker, 1987) also shown to be relevant to compensation size and structure. Murphy (1999) provides a review of earlier literature.

The structure of the compensation package may also be affected by financial reporting considerations. Before the requirement of SFAS 123(R) to expense stock options, firms were able to use stock option grants as part of an income management strategy. Matsunaga (1995), Klassen and Mawani (2000) and Carter et al. (2007) provide evidence linking the use of stock options to the extent that the firm is below the target level of income, and the use of income-increasing accounting methods. These findings suggest that the design of the compensation contract can be influenced by factors unrelated to agency considerations, such as accounting standards and earnings management.

More recent research has suggested additional factors influencing the design of compensation contracts. These include high takeover protection and the power of CEO to influence corporate governance (Davila and Penalva, 2006), the power of external shareholders, ownership of the board of directors and risk of default (Cyert et al., 2002), and cronyism (Brick et al., 2006). This stream of the literature suggests that stronger monitoring and governance act as alternative mechanisms to imposing managerial control over the design of the compensation contract. At the same time it implies that poor monitoring and governance may lead to sub-optimal contracts permitting managers to extract excess rents and exercise less effort.

Deviations from optimal contracting might indeed be an important determinant of compensation structure. Core and Guay (1999) model optimal equity incentive levels using a number of firm and director characteristics, and find that equity incentive grants are negatively related to deviations of CEOs' holdings from optimal levels. Their analysis highlights how changes in firm and director characteristics may misalign CEO incentives and lead to sub-optimal contracts, and how firms may restore optimality by revising equity based compensation granted to CEOs in subsequent periods. 
Other studies have focused on firms' responses to clear evidence of misaligned CEO incentives. Cheng and Farber (2008) examine compensation grants following earnings restatements, and find that subsequent compensation arrangements revise down the level of incentive grants. Based on the hypothesis that restatements are more likely to result with excessive equity incentive holdings and over-incentivization (following from Efendi et al., 2007), they predict and find that compensation committees revise option grants downwards following restatements. This is consistent with firms taking remedial action when aggressive reporting is sufficiently severe to warrant an earnings restatement.

\subsection{Outcomes of executive compensation contracts}

Unlike shareholders, who can diversify their risk via a portfolio of holdings, managers have greater exposure to undiversified risk. This may cause them to forego risky higher-return projects, resulting in sub-optimal risk-taking. In the standard agency model, options are granted in order to help mitigate executive risk-aversion, providing an incentive to invest in higher-return projects, and to improve performance. Since Jensen and Murphy (1990), there has been considerable growth in equity compensation granted to executives. This may have been motivated by criticism of low pay-performance sensitivity, the favorable accounting treatment of stock-based compensation, and the desire to provide greater alignment of interests between managers and shareholders. This has led to managers building up substantial portfolios of ordinary shares, restricted shares, and stock options.

The relationship between equity incentives and subsequent investment and risktaking has been examined empirically by a number of studies. Agrawal and Mandelker (1987) find a positive relationship between ordinary share and options holdings and variance around investment, while Guay (1999) and Cohen et al. (2000) find a positive relationship between CEOs' wealth sensitivity to equity risk and contemporaneous stock volatility. Coles et al. (2006) link CEOs' wealth sensitivity to investment decisions, particularly R\&D and capital expenditure. Rajgopal and Shevlin (2002) find a positive relationship between option holdings and risk, using firms in the oil and gas industry, while Balachandran et al. (2010) link equity grants to the probability of default in the banking industry. Cheng and Farber (2008) also provide evidence linking option-based compensation to risk-taking. Consistent with the hypothesis that the reduced option-based compensation following earnings restatements decreases the convexity of CEO compensation contracts and the willingness to take on excessively risky projects, they 
find that restatement firms that reduce option compensation experience a significant decrease in stock return volatility (a common proxy for the riskiness of investments).

While the literature has established a positive association between the equity incentives in CEO contracts and risk in line with agency predictions, it has also offered evidence of an association with sub-optimal outcomes, e.g. earnings management and earnings restatements. Most evidence focuses on how CEO incentive pay induces earnings management (Cheng and Warfield, 2005; Bergstresser and Philippon, 2006), with an emerging body of literature linking the structure of executive pay to earnings restatements. Efendi et al. (2007) find that the level of CEOs' options that are deep inthe-money increases the likelihood of earnings restatements. Burns and Kedia (2006) find that the likelihood of misreporting also increases with the sensitivity of CEO option holding to stock price and volatility.

Taken together, evidence on the determinants and outcomes of the structure of CEOs compensation contracts suggests that while theoretically optimal CEO contracts exist, changes in firm and director characteristics over time may cause incentives to become misaligned, leading to sub-optimal outcomes such as excessive risk-taking, underperformance, earnings management and earnings restatements. Our paper focuses on excessive risk-taking as a sub-optimal outcome and how compensation committees may amend option-based compensation in subsequent periods to restore optimality. In examining this aspect of the design and efficacy of option-based compensation, we also probe the role of aggressive reporting as another sub-optimal outcome, which may be highly correlated with excessive risk-taking.

\subsection{Excessive risk-taking and revisions of CEO option-based compensation}

Similar to Core and Guay (1999), we hypothesize that optimal levels of equity incentives exist, but managers' equity incentives become misaligned with the optimal levels over time due to shifts in the optimal levels or the equity incentives provided by equity portfolios. Optimal levels of incentives shift due to changes over time in determinant firm and director characteristics (e.g. free cash flow, CEO tenure). Incentives provided by equity portfolios shift due to managers periodically buying and selling stock and exercising options, or to changes in stock price, return volatility and vesting periods. Consistent with firms using stock-based compensation effectively, Core and Guay (1999) find that when managers' incentives become misaligned with optimal levels, firms restore 
optimality by reducing (increasing) stock option grants when CEOs' incentives exceed (undershoot) the optimal level.

We focus on sub-optimality driven by excessive risk-taking. Granting of stock options to induce managers' effort raises risk-taking bias in investment project choice, as it shifts the CEOs' preferences towards riskier investment opportunities (Laux, 2010). The asymmetric payoff function to stock options protects managers from the downside potential and induces them to undertake risky investments. ${ }^{2}$ Several studies find that the convex payoffs of stock options may indeed reduce agency costs by encouraging risktaking by managers of firms with high growth opportunities (Agrawal and Mandelker 1987; Guay 1999; Cohen et al. 2000 Bryan et al., 2000; Rajgopal and Shevlin 2002; Coles et al., 2006; Balachandran et al. 2010). The question, however, is not whether stock options should be part of the equity incentive mix provided to executives, but whether option grants should be limited when managers have already been over-incentivized and engage in excessive risk-taking. ${ }^{3}$ If excessive risk-taking is indeed detected as a deviation from optimality, compensation committees that use stock-based compensation effectively would adjust CEOs' incentives to the optimal level by reducing the number of the stock options grants. We therefore hypothesize that:

H1: Excessive risk-taking is associated with subsequent decreases in CEOs' optionbased compensation

\subsection{The damaging effect of aggressive reporting}

When CEOs overinvest in risky projects, we expect that boards will revise stock option grants, so long as they detect the deviation from optimality. Earnings management, however, may deter this detection. When risky projects do not yield the expected returns, managers are incentivized to maintain their stock overvaluation by artificially inflating returns through aggressive reporting (Jensen, 2005). Strong pressure comes from the market, which rewards firms that continue to meet rising expectations of future earnings,

\footnotetext{
${ }^{2}$ The implicit assumption here is that managers' utility functions exhibit declining risk aversion, or at the very least managers are less diversified than shareholders and may therefore forego positive NPV projects that are very risky (Core and Guay, 1999; Coles et al., 2006). Stock options then serve as one solution to this agency problem by providing managers with convex payoffs that reduce their risk-aversion and encourage investments in riskier assets.

${ }^{3}$ A self-driven counteracting incentive to risk-taking is arguably CEOs' concern about dismissal as undertaking risky projects are associated with higher risks. Fear of dismissal may bias CEOs in continuing business as usual, and is more of a concern in industries with less valuable investment opportunities (Laux 2010) and industries where the volatility in performance outcomes is driven by factors unrelated to CEO effort (Bushman et al. 2010). In those circumstances risk-taking bias is more likely to outweigh the conservatism bias induced by fear of dismissal.
} 
and from managers themselves, who reap benefits from rising prices, such as higher compensation. But when firms use aggressive reporting to meet or exceed market expectations, long-term value is destroyed.

Jensen (2005) suggests that indeed stock option based compensation has fuelled rather than deterred the use of aggressive reporting to maintain stock overvaluation. There is ample of evidence pointing to stock option compensation motivating earnings management (for reviews see Cheng and Warfield, 2005; Bergstresser and Philippon, 2006; Grant et al. 2009) and earnings restatements (Burns and Kedia, 2006; Efendi et al., 2007). However, there is little evidence examining reverse causality, i.e. the extent to which compensation committees take aggressive reporting into account in CEO compensation contracts. Cheng and Farber (2008) find that firms reduce the optionsbased compensation after earnings restatements, suggesting that firms take remedial action only after the problem with aggressive financial reporting is severe and publicly known. This suggests that compensation committees are unable to detect earnings management allowed within the scope of GAAP (e.g. amount of income increasing accruals or frequency of meeting earnings benchmarks) and take into account in the design of compensation contracts, until it is too late. Corporate scandals and failures of reputable firms such as Xerox, Royal Dutch Shell, WorldCom, Enron, Nortel, and Lehman Brothers are only a few examples confirming the damaging effects of aggressive reporting, and the fuelling role of compensation contracts. Subsequent investigation into these cases often highlighted the poor structuring of option contracts that persistently created incentives to artificially inflate reported earnings in order to keep stock prices high and rising. This empirical and anecdotal evidence questions the ability of compensation committees to prevent aggressive reporting through compensation contracts. Therefore we do not expect new stock option grants to respond to prior instances of managers' aggressive reporting.

The opacity of aggressive reporting also raises the possibility that overinvestment in risky projects goes undetected or uncorrected for. Managers may mask the outcome of poorly performing risky projects using aggressive reporting. This is possible if the artificially inflated returns on risky projects lead compensation committees to raise the threshold level of risk tolerance. This would increase acceptable levels of CEOs' risktaking, preventing detection of true excessive risk-taking. In this case, the likelihood that the board revises stock grants for excessive risk-taking will decrease with the extent of 
aggressive reporting. We therefore expect any response to excessive risk-taking to weaken in the presence of aggressive financial reporting.

H2: The association between excessive risk-taking and changes in CEOs' option-based compensation is attenuated with aggressive financial reporting.

\subsection{Detecting excessive risk-taking through CEOs' stock option holding}

The first characteristic that compensation committees may use to detect excessive risktaking is CEO holding of exercisable stock options that are deep in-the-money. This CEO characteristic entails risk for the firm, based on economic and behavioral incentives. A rational executive should prefer holding an exercisable stock option to exercising the option and holding the stock. In both cases there is the same potential upside gain for the executive, but in the latter case, the potential downside loss, up to the exercise price, is borne by the executive. As long as the executive chooses not to exercise an in-the-money option, the risk of any future downside loss below the exercise price remains with the firm -if the option is exercised, future risk and losses are shared between the firm and the executive. Therefore, the continued holding of in-the-money exercisable options by CEOs increases the risk of the firm compared to the exercise of the option, and prolongs the asymmetric payoff function of options (Efendi et al., 2007). As continued holding of stock options reduces CEO risk-aversion, it also provides incentives for the CEO to undertake riskier projects and potentially aggressive reporting to meet targets and keep the equity of their firms overvalued (Jensen 2005). Efendi et al. (2007) also argue that CEOs' holding of exercisable options that are deep-in-the money reflects incentives to create or maintain overvaluation of stocks through earnings management or aggressive financial reporting, and provide evidence linking the continued holding of stock options to the likelihood of misstated financial statements.

A CEO may also continue to hold exercisable in-the-money options based on positive beliefs about the firm's future prospects. If the CEO is optimistic about the firm's prospects, he will prefer to hold the exercisable option instead of exercising and selling the share. If he believes that the stock price will decrease, he will exercise his exercisable options, sell the stock, and lock in gains made above the exercise price. Observed holding of exercisable options might then reflect a CEO's positive beliefs about the firm, or what the CEO would like to signal. However, this continued holding of exercisable options may also reflect an overly optimistic outlook and can lead CEOs to 
overestimate investment returns and engage in riskier investment activity (Malmendier and Tate, 2005; 2008) and result in greater return volatility (Hirshleifer et al., 2010). Malmendier and Tate $(2005 ; 2008)$ characterize CEOs that hold exercisable options that are deep in-the-money as overconfident and find that these CEOs overestimate returns on investment projects and mergers and acquisitions. The outcome of this investment behavior suggests that the firm bears a higher amount of risk than necessary, since the alternative would have been to invest in a less risky project with the same (lower) return. CEOs that continue to hold exercisable options that are deep in-the-money are also more likely to finance projects with debt rather than equity (Malmendier et al., 2010) and make lower dividend payouts (Deshmukh et al., 2009). ${ }^{4}$

We calculate our first measure of excessive risk-taking by observing the CEOs continued holding of in-the-money stock options when they are exercisable. Malmendier and Tate (2005) classify CEOs as "optimistic" if they continue to hold options which are at least $67 \%$ in the money, provided that the CEO has demonstrated this holding behavior at least twice in the sample period. This $67 \%$ threshold is also applied by Sudarsanam and Huang (2007) and Hirshleifer et al. (2010). Campbell et al. (2010) use a higher benchmark of $100 \%$ moneyness, since they aim to identify CEOs who are relatively more optimistic than others. To calculate the level of moneyness, Malmendier and Tate (2005) rely on a proprietary data set of stock and stock option holdings (from Yermack, 1995 and Hall and Liebman, 1998), which provides details about exercise prices, number of underlying shares, and time to maturity for a set of data from 1980-1994. Since we do not have the same data on a per-grant basis, we calculate moneyness using the difference between the fiscal year-end stock price and the estimated exercise price of exercisable options. We use the approximation proposed by Core and Guay (2002) to estimate the average exercise price of exercisable options, the same method used by Campbell et al. (2010), Hirshleifer et al. (2010), and Sudarsanam and Huang (2007).

Using data from Execucomp, we first estimate the per-option realizable value by taking the total realizable value of exercisable options (Execucomp's variable $\left.O P T \_U N E X \_E X E R \_E S T \_V A L\right)$ and dividing by the number of exercisable options $\left(O P T_{-} U N E X \_E X E R \_N U M\right)$. We then estimate the average exercise price

\footnotetext{
${ }^{4}$ Related literature on CEO overconfidence using alternative measures also finds that overconfident CEOs are also likely to make bold actions, leading to volatile organizational performance (Chatterjee and Hambrick, 2007), engage in earnings management or fraud (Schrand and Zechman, 2008), and are more likely to miss voluntary earnings forecasts (Hribar and Yang, 2010), use short-term debt, and repurchase shares (Ben-David et al., 2008).
} 
(Est_Exercise_Price) by subtracting the per-option realizable value from the fiscal yearend share price $(P R C C F){ }^{5}$ Like Campbell et al (2010) and Hirshleifer et al. (2010), we calculate the percentage moneyness of the exercisable option a ratio of the stock price to estimated exercise price less 1:

$$
\text { Moneyness }=\frac{\text { PRCCF }}{\text { Est_Exercise_Price }}-1
$$

where

$$
E s t_{-} \text {Exercise }{ }_{-} \text {Price }=\frac{O P T_{-} U N E X_{-} E X E R_{-} E S T_{-} V A L}{O P T_{-} U N E X_{-} E X E R_{-} N U M}
$$

We classify CEO-years where Moneyness $>100 \%$ as high-holding years (Moneyness 100) starting with the first time the holding behavior is observed, provided that he or she has demonstrated Moneyness $>100 \%$ at least twice over the period. We also apply Malmendier and Tate's (2005) 67\% threshold (Moneyness67). As we are interested in responses to observed holding behaviour, both variables are lagged by one period, to reflect holding characteristics at the beginning of the period.

\subsection{Detecting excessive risk-taking through overinvestment in $R \& D$}

CEO holding of exercisable options that are deep in-the-money offers an embracing predictor of managers' excessive risk-taking, as it has been found to predict corporate investment distortions, risky financing policies, and aggressive earnings forecasting and reporting. ${ }^{6}$ Prior literature on compensation schemes, however, tends to focus on excessive risk-taking on investment decisions with an explicit focus on the firm's investment in R\&D (Bryan et al., 2000; Cheng and Farber, 2008; Coles et al., 2006). CEO holding of exercisable options that are deep in-the-money may be a poor predictor of overinvestment to the extent it also reflects other forms of risky behavior, e.g. risky financing policies, earnings or expectations management in response to equity overvaluation. To mitigate concern over this possibility, we also examine overinvestment in $R \& D$ as an indicator of excessive risk-taking. ${ }^{7}$

\footnotetext{
${ }^{5}$ Variable names in capital letters are those used by Execucomp on the WRDS platform.

${ }^{6}$ Deshmukh et al. (2009) relate CEO's excessive holding of exercisable options to lower dividend payouts, while Efendi et al. (2007) link CEOs' sizeable holdings of in-the-money stock options to overvalued equity and the likelihood of misstated financial statements.

${ }^{7}$ Stock return volatility has been also used as a proxy for the riskiness of investments (see Cheng and Farber 2008). Stock return volatility may capture risk relating to the firm's operating, financing and reporting decisions, yet it is difficult to normalize and inevitably affected by stock market anomalies. Also stock returns may be beyond the control of managers simply reflecting changes in economy-died or industry-wide circumstances.
} 
We calculate an identifier of excessive $R \& D(R i s k y R \& D)$ for firms in the top quintile of abnormal $\mathrm{R} \& \mathrm{D}(A R D)$. To derive a measure of abnormal investment in $\mathrm{R} \& \mathrm{D}$, we follow Berger (1993) and Gunny (2009) to estimate the normal R\&D expense as follows:

$$
R D_{i, t}=a_{0, i}+a_{1, i} R D_{i, t-1}+a_{2, i} \operatorname{FUNDS}_{i, t}+a_{3, i} C A P E X_{i, t}+a_{4, i} \operatorname{TOBINQ}_{i, t}+a_{5, i} \text { ROA }_{i, t}+e_{i, t}
$$

where $R D_{i, t}$ and $R D_{i, t-1}$ are the levels of firm $i$ 's R\&D divided by sales in years $t$ and $t-1$, $F U N D S_{i, t-1}$ is a proxy for the level of firm $i$ 's pre-R\&D cash flow in year $t$ (i.e. pre-tax income plus interest expense, $\mathrm{R} \& \mathrm{D}$ and depreciation divided over sales, $C A P E X_{i, t}$ is the level of firm $i$ 's capital expenditure in year $t$ (excluding $R \& D$ ) divided by sales, $\operatorname{TOBINQ}_{i, t}$ is the level of firm $i$ 's Tobin's $\mathrm{q}$ in year $t$ (total market capitalization, plus book value of preferred stock, long-term debt and short-term debt divided over assets), and $R O A_{i, t}$ is the level of firm $i$ 's income before extraordinary items divided over average total assets in year $t{ }^{8} \mathrm{R} \& \mathrm{D}$ divided by sales is a common measure of R\&D intensity in the industrial organization literature and among capital market participants. We deflate all remaining financial variables by sales to control for heteroskedasticity. Lagged R\&D intensity $\left(R D_{i, t-1}\right)$ controls for firm-level innovation opportunities. Firms that have identified more potentially profitable innovation opportunities may be expected to spend more on $R \& D$ each year. Lagged $R \& D$ intensity also reduces the autocorrelation in the residuals caused by the non-stationarity in the time-series process of $R D$. The level of internal funds (FUNDS) may affect R\&D expenditure as $\mathrm{R} \& \mathrm{D}$ projects may be rationed. Evidence of an association between internal funds and R\&D has been found mainly for smaller firms (Himmelberg and Petersen, 1994). Remaining capital expenditure (CAPEX) controls for the potential competition of resources between capital expenditure and R\&D projects. TOBINQ proxies for the marginal benefit to the marginal cost of implementing a new investment project. As prior literature provides evidence that the measurement error in proxies of managerial opportunism is associated with operating performance (Kothari et al. 2005), equation (1) also includes return on assets (ROA).

$\mathrm{R} \& \mathrm{D}$ levels in certain concentrated industries have been found to be a major element of competition, so a firm's R\&D spending is expected to be influenced by its rivals. We

\footnotetext{
${ }^{8}$ We present detailed definitions of all variables in the Appendix.
} 
therefore estimate equation (1) for each of Fama and French's (1997) 48 industry groups with at least 20 firms in each industry-year combination, to ensure efficient parameter estimation. Annual cross-sectional estimations of equation (1) yield firm- and yearspecific residuals, $e_{i, t}$, representing abnormal R\&D expenses $(A R D)$. As we are interested in overinvestment, we form quintiles based on $A R D$ ( 0 is the lowest, 4 the highest quintile). RiskyR\&D equals 1 for all firm-year observations in the top quintile of $A R D$ and 0 otherwise.

\subsection{Measuring aggressive reporting}

Efendi et al. (2007) find that when CEOs have sizable holdings of in-the-money stock options, firms are more likely to restate financial statements. These stock holdings reflect the effects of both large option grants and equity overvaluation, which incentivize managers to engage in earnings management. To investigate the role of aggressive reporting in the design and efficacy of CEO compensation contracts, we extract measures of abnormal accruals and focus on firms with excessively positive abnormal accruals. As we focus on the role of aggressive reporting, especially with regards to firms that undertake excessively risky projects, it is vital that we control for the effect of these projects in true underlying operating performance. We therefore follow Kothari et al. (2005) to estimate performance-adjusted abnormal accruals, $P A A A$, and identify those in the top quintile with an indicator variable for Aggressive_Reporting. The estimation process starts with cross-sectional estimation of the modified Jones (1991) model:

$$
\frac{T_{i, t}}{\operatorname{Assets}_{i, t}}=\beta_{1, i} \frac{1}{\operatorname{Assets}_{i, t}}+\beta_{2, i} \frac{\Delta \operatorname{Rev}_{i, t}}{\operatorname{Assets}_{i, t}}+\beta_{3, i} \frac{P P E_{i, t}}{\operatorname{Assets}_{i, t}}+u_{i, t}
$$

where $T A_{i, t}$ is the firm's total accruals at the end of year $t$, Assets $s_{i, t-1}$ is firm $i$ 's average total assets in year $t, \triangle R E V_{i, t}$ is firm $i$ 's change in revenues between year $t-1$ and $t$, and $P P E_{i, t}$ is firm $i$ 's gross value of property, plant and equipment at the end of year $t$. The industry- and year-specific parameter estimates from equation (2) are then used to estimate firm-specific normal accruals:

$$
N A_{i, t}=\hat{\beta}_{1} \frac{1}{\operatorname{Assets}_{i, t}}+\hat{\beta}_{2} \frac{\Delta \operatorname{Rev}_{i, t}-\Delta A R_{i, t}}{\operatorname{Assets}_{i, t}}+\hat{\beta}_{3, i} \frac{P P E_{i, t}}{\operatorname{Assets}_{i, t}}
$$


where $\Delta A R_{i, t}$ is firm $i$ 's change in accounts receivable between year $t-1$ and year $t$. We then calculate abnormal accruals, $A A_{i, t,}$ as firm $i$ 's abnormal accruals in year $t$, equal to $T A_{i, t} /$ Assets $_{i, t-1}-N A_{i, t}$.

Following Kothari et al. (2005), we then obtain performance adjusted abnormal accruals $\left(P A A A_{i, t}\right)$ by matching each firm-year observation with the firm with the closest return on assets, ROA, in the current year, with the same two-digit SIC code. As we are interested in excessive positive accruals, we form quintiles based on the performanceadjusted abnormal accruals, $P A A A_{i, t}=A A_{i, t}-A A_{p, t}$, where $A A_{p, t}$ is the abnormal accrual of the matched firm. Aggressive_Reporting equals 1 for firm-year observations in the top quintile of $P A A A$, and 0 otherwise.

\subsection{Excessive risk-taking and changes in CEO option based compensation}

To test our hypotheses we examine the association between excessive risk-taking and subsequent changes in CEO stock option grants using the following multivariate specification:

$$
\begin{aligned}
\Delta{\text { Options_Grants } \%_{i t}=} & a_{0}+a_{1} \text { ExcessiveRiskMeasures }_{i, t-1}+\text { BControls }_{i, t-1} \\
& + \text { YearDummies }+\varepsilon_{i t}
\end{aligned}
$$

Similar to Cheng and Farber (2008), we define the change in stock options grants, $\Delta$ Options_Grants, as follows:

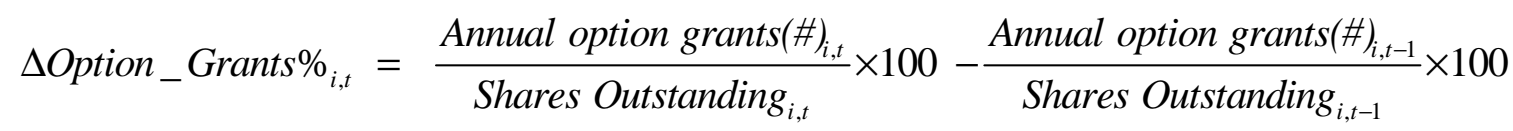

where Annual option grants(\#) is the number of options granted to the CEO during the year. Taking changes instead of levels of option grants controls for the impact of timeinvariant firm characteristics on CEO compensation structures, such as industry membership. As measures of excessive risk we first examine CEOs' holding of exercisable options that are deep in-the-money (Moneyness67 or Moneyness 100), then overinvestment in $\mathrm{R} \& \mathrm{D}$, RiskyR\&D. Since we need to consider information available to compensation committees at the time of the decision of the option grants for this year, we use lagged values of our measures of excessive risk. Using lagged values also mitigates 
concerns over the endogenous nature of managers' risk-taking behavior. We endorse Coles et al. (2006) argument that managerial compensation scheme and policy choices are jointly determined and extend the argument to cover managers' risk-taking behavior. To mitigate concern over the endogeneity of excessive risk, our set of controls include proxies for managerial incentives shaping risk-taking behaviour (e.g. leverage, growth, size, cash flow shortage, stock returns, etc). If, consistent with H1, excessive risk-taking is associated with subsequent decreases in CEOs' option-based compensation, we expect $a_{1}$ in equation (4) to be negative.

In our set of control variables, we include lagged changes in a number of factors affecting CEO equity holdings, as identified by Core and Guay (1999), Hanlon et al. (2003) and Cheng and Farber (2008). ${ }^{9}$ We initially include CEO characteristics, namely cash compensation (CashCompensation), stock ownership, and turnover (NewCEO). As cash compensation could be invested outside the firm, it reduces managers' risk-aversion and therefore the need to grant stock options to encourage investment in riskier assets. On the other hand, cash compensation may act as a complement to option grants offsetting the additional risk that managers bear once they start engaging in riskier projects. CEO stock ownership provides a proxy for the extent CEOs' interests are aligned with those of shareholders. When ownership is low, compensation committees grant more options to align incentives. Similar to Cheng and Farber (2008), we use three measures of CEO stock ownership, the actual number of shares owned (Shares_Own), the number of excercisable options (Exercisable_Options) and the number of unexercisable options (Unexercisable_Options). We expect structural changes in option grants after a CEO succession. While there has been ample evidence on the association of CEO turnover with poor firm performance and risk (for a summary, see Bushman, 2010), there is no evidence on option-based compensation of incoming CEOs. Evidence that firms with more equity-based compensation for directors are more likely to dismiss their CEOs early (Ertugrul and Krishnan, 2011) suggests that compensation committees would revise option grants downwards for incoming CEOs. An additional reason for lower demand for

\footnotetext{
${ }^{9}$ Core and Guay (1999) build a model for CEO's portfolio holdings of equity incentives drawing from the literature examining the determinants of managerial ownership (Demsetz and Lehn, 1985; Jensen, 1986; Himmelberg et al., 1999). The factors include firm and director characteristics affecting monitoring difficulty and agency costs.
} 
option based compensation of new CEOs, is that they tend to be already incentivized enough to undertake innovative projects (Bereskin and Hsu, 2010). ${ }^{10}$

Next, we include firm characteristics, namely firm size (Size), growth opportunities $(B / M)$, reporting of operating losses (NetOperatingLoss), cash flow shortfall (CashShortFall), leverage (LEV), returns (Return), past return (PastReturn), stock return volatility ( $\sigma$ Return), $R \& D$, and remaining capital expenditure $(C A P E X)$. We include firm size, as prior research suggests that equity incentives increase with firm size. Larger firms are more complex and need to grant more options to motivate effort and risk-taking by their managers. We control for growth opportunities as they make it more difficult for shareholders to evaluate managers' actions, increasing monitoring difficulty and the need for stock options to lower monitoring costs. Alternatively, a richer investment opportunity set (lower $B / M$ ) may induce boards to grant more options to incentivize managers to exploit it. Stock based compensation does not affect a company's current cash flow and may be the preferred way to compensate managers when the companies face cash shortages or operating losses. Accordingly we include an indicator of firms with operating losses (NetOperatingLoss), and a measure of cash constraints based on the excess of investment outflows and dividend payments over operating cash flows (CashShortFall). We control for leverage (LEV), as debt financing may act as a substitute monitoring mechanism to stock options. Also, leveraged firms rely less on option-based compensation, as debt holders will demand a higher risk premium if managers start pursuing risky investments that transfer wealth from debtholders to shareholders. We control for the potential association between CEO compensation and firm performance by including current year returns (Return), and prior year stock returns (PastReturn). The volatility of stock returns ( $\sigma$ Return) proxies for normal risk. Normal risk is expected to be positively associated to stock option grants as firms operating in noisier, i.e. more uncertain and unpredictable, environments face higher monitoring difficulty and thus greater demand for option-based compensation to reduce monitoring costs (Demsetz and Lehn, 1985). As a further proxy for growth opportunities we include $R \& D$ and remaining capital expenditure (CAPEX). These investment expenditures also explicitly account for the impact of investment policies on the design of CEO compensation contracts (Coles et al., 2006). To the extent $R \& D$

\footnotetext{
${ }^{10}$ Bereskin and $\mathrm{Hsu}$ (2010) find that CEO turnover is associated with greater quantity and quality of future innovation (i.e. more patents, citations) and that the innovation is higher for new internal compared to new external CEOs.
} 
$(C A P E X)$ represents riskier (safer) investment policy choices, we expect option grants to be increasing (decreasing) in $R \& D(C A P E X)$.

Finally we add year dummies to control for any time-specific variation in stock option grants not captured by the independent variables. Because we model the contemporaneous change in option-based compensation, we use the lagged changes of all control variables (similar to Core and Guay, 1999 and Cheng and Farber, 2008), except for dummy variables for which we use lagged values. We estimate equation (4) using OLS with robust standard errors. We report the robustness of our results to alternative estimation procedures in Section 5.4.

To test our second hypothesis, we extend equation (4) to include Aggressive_Reporting and an interaction term between ExcessiveRiskMeasures and Aggressive_Reporting as follows:

$$
\begin{aligned}
\Delta{\text { Options_Grants } \%_{i t}} & =a_{0}+a_{1} \text { ExcessiveRiskMeasures }_{i, t-1}+a_{2} \text { Aggressive_Reporting }_{i, t-1} \\
+ & a_{3} \text { ExcessiveRiskMeasures }_{i, t-1} \times \text { Aggressive_Reporting }_{i, t-1} \\
+ & \beta \text { Control }_{i, t-1}+\text { YearDummies }+\varepsilon_{i t}
\end{aligned}
$$

If, in line with $\mathrm{H} 2$, the association between excessive risk-taking and changes in CEOs' option-based compensation is attenuated with aggressive financial reporting, we expect the coefficient on the interaction term, $a_{3}$, to be positive.

\section{Sample and summary statistics}

Our initial sample is composed of an unbalanced panel of CEOs of firms covered by Execucomp from 1992-2008, which have accounting data from Compustat, and market data from CRSP. Execucomp covers firms that are members or have been members of the S\&P 1500 index. Our requirement to examine the exercising or holding behavior of executives limits our sample to firms with CEOs who have exercisable stock options, like Campbell et al. (2010). Our use of a change specification and also lagged variables causes us to lose an additional two years of observations. Our final sample consists of 11,789 firm-years, and 1,786 unique firms, from 1994-2008.

Table 1 presents basic descriptive statistics of our sample. Our primary dependent variable, $\Delta$ Options_Grants $\%_{t}$ is relatively constant, with a median value of 0 , showing no change in option grant over the previous period. $26.3 \%$ of executives are classified as having high moneyness, holding exercisable options that are at least $100 \%$ in the money (Moneyness 100). If this threshold is relaxed to 67\% (Moneyness67), the proportion of the 
sample increases to $38.2 \%$. Both RiskyR\&D $D_{t-1}$ and Aggressive_Reporting t-l $_{\text {indicate firms }}$ in the top quintile of the sample for excess $\mathrm{R} \& \mathrm{D}(A R D)$ and performance-adjusted abnormal accruals $(P A A A)$, respectively. The mean and median change in the CEO's number of exercisable options ( $\Delta$ Exercisable_Options $\left._{t-1}\right)$ is positive, and the change in the number of unexercisable options (AUnexercisable_Options $\left.s_{t-1}\right)$ is negative, suggesting that over the entire sample, unexercisable options are decreasing and exercisable options increasing. The positive mean and median change in firm size, $\Delta$ Size $_{t-1}$ show that the sample firms are growing over time. Table 1 also presents the distribution of our other control variables, including change in operating and stock returns. Both $\Delta R \& D_{t-1}$ and $\triangle C A P E X_{t-1}$ are close to zero, suggesting that there is little change from year to year.

Table 2 presents the correlation between regression variables. It shows a positive relationship between both forms of Moneyness and Risky $R \& D$, and a significant negative correlation between $\Delta$ Options_Grants $\%_{t}$ and $\Delta$ Unexercisable_Options $s_{t-1}$. This may reflect a tendency of firms to replace vesting options are replaced with new grants. There is also a negative correlation between $\Delta$ Unexercisable_Options $s_{t-1}$ and $\Delta$ Exercisable_Options $s_{t-1}$, which may result from the transfer of vesting stock options from Unexercisable_Options to Exercisable_Options, and for exercised options (a decrease in Exercisable_Options) to be replaced by new Unexercisable_Options, or from CEOs regulating their total option portfolio by exercising exercisable options upon receiving new unexercisable grants.

The largest correlation, other than that between Moneyness100 and Moneyness67, is a negative correlation between $\Delta$ Size $_{t-1}$ and $\Delta$ Cash Compensation $_{t-1}$ (both Spearman and Pearson), consistent with Cheng and Farber (2008). There is also a significant negative correlation between $\Delta$ Return $_{t-1}$ and $\Delta$ PastReturn $_{t-1}$, and between $\Delta B / M_{t-1}$ and $\Delta$ Return $_{t-1}$, since $B / M$ moves inversely to Return. The highest univariate correlation is between Moneyness 100 and Moneyness67, but these are not used in the same model.

\section{Results}

\subsection{The impact of excessive risk-taking on changes in CEO option compensation}

Table 3 reports the results of regressing $\Delta$ Options_Grants $\%_{t}$ on excessive risk-taking captured by CEOs' option holding behavior and controls. Column 1 reports results using Moneyness $100_{t-1}$ as a measure of excessive risk-taking, i.e. an indicator of directors holding exercisable options that are at least $100 \%$ in the money. The coefficient on 
Moneyness $100_{t-1}$ is negative and significant $(-0.032, t=-3.30)$, consistent with the change in option-based compensation as a percentage of total shares outstanding being $3.2 \%$ lower for all CEOs that hold exercisable options at least $100 \%$ in the money at the beginning of the year compared to CEOs that do not exhibit this option holding behavior. This result holds when we use a lower threshold of $67 \%$ moneyness in Column 2. The coefficient on Moneyness6 $7_{t-1}$ is also negative and significant $(-0.028, t=-3.32)$, suggesting that the $67 \%$ moneyness is also a reasonable threshold for detecting risky option holding behavior.

The coefficients to our control variables, $\Delta$ Exercisable_Options $_{t-1}$, $\Delta$ Unexercisable_Options $_{t-1}$, and $N e w C E O_{t-1}$ are negative and significant in line with prediction. This is consistent with CEOs with high exercisable and unexercisable option ownership and newly appointed CEOs being awarded fewer option grants. The latter finding supports our argument that compensation committees award new CEOs fewer option grants. The result refers to new internal CEOs. ${ }^{11}$ Since, Bereskin and Hsu (2010) find that it is new internal CEOs that exhibit the highest and better innovation after their appointment, this suggests that the fewer option grants of newly appointed CEOs is due to them being already sufficiently incentivised to invest in riskier assets. ${ }^{12}$ Among the remaining control variables, the coefficient on $\Delta$ Size is negative and significant opposite to our prediction. Cheng and Farber (2008, p. 1234) report similar findings when they test the number of option grants. The negative association between firm size and changes in option-based compensation might be due to larger firms facing lower (instead of higher) monitoring difficulty, as they often have advanced corporate governance mechanisms in place to enforce scrutiny of CEOs' behavior. The coefficients on AReturn and APastReturn are negative and significant consistent with firms with higher current and past returns awarding their CEOs fewer option grants. Prior research suggests a positive relation between a firm's stock returns and total CEO compensation (Baber et al., 1996) and between past returns and the value of stock option grants (Hanlon et al., 2003). Our results may, however, be due to our core tests focusing on the number instead of the value of option grants, which is mechanically affected by changes in the firm's stock

\footnotetext{
${ }^{11}$ Given that $\Delta$ Options_Grants $\%_{i t}$ is not definable until the second year of office for a newly appointed external CEO (as it is a change variable), our $N e w C E O_{t-l}$ indicator captures the average change $\Delta$ Options_Grants $\%_{i t}$ for new internal CEOs.

${ }^{12}$ Bereskin and $\mathrm{Hsu}$ (2010) find that CEO turnover is associated with greater quantity and quality of future innovation (i.e. more patents, citations) and that the innovation is higher for new internal compared to new external CEOs.
} 
price, i.e. as share prices rise, firms award fewer option grants for the same amount of compensation. The coefficients on cash compensation, book-to market ratio, cash constraints, leverage, stock return volatility, $R \& D$ and capital expenditure are not significant. ${ }^{13}$ This is partly due to issues of multicollinearity; if we repeat the regressions using only this set of controls (untabulated), the coefficients on $\triangle$ CashCompensation and $\triangle R \& D$ become significant $(-9.519, t=-1.78$ and $0.135, t=2.08$ respectively $)$. This means that CEOs with higher cash compensation receive lower option grants, and that as predicted, firms investing increasingly in R\&D grant their CEOs more stock options.

In the third column of Table 3 we repeat the analysis using the alternative measure of excessive risk-taking based on firm's overinvestment in $\mathrm{R} \& \mathrm{D}, R i s k y R \& D$. The coefficient on RiskyR\&D is negative and significant $(-0.026, t=-2.44)$, indicating that changes in option-based compensation as a percentage of total shares outstanding are $2.6 \%$ lower for all firms that invested excessively in $\mathrm{R} \& \mathrm{D}$ in the prior year compared to remaining firms. Collectively, the results in Table 3 are consistent with our first hypothesis that excessive risk-taking, as proxied either by CEOs' holding of exercisable options that are deep in-the-money or firms' excessive investment in $R \& D$, is associated with subsequent decreases in CEOs' option-based compensation. Consistent with compensation committees using option-based compensation effectively, this evidence suggests that they are able to detect potential excessive risk-taking and factor this in revising stock option grants for the following year.

\subsection{CEOs' holding of exercisable options that are deep in-the-money versus overinvestment in $R \& D$ as a measure of excessive risk-taking}

To assess the extent of overlap between our two measures of excessive risk-taking, CEOs' holding of exercisable options that are deep in-the-money and firms' excessive investment in R\&D, we next repeat the regressions of $\Delta$ Options_Grants\% including both measures in the model. Table 4 reports the results, showing that the coefficients on both Moneyness100 and RiskyR\&D remain negative and significant $(-0.030, t=-3.07$ and $-0.022, t=-2.12)$. The result holds when we use a lower threshold of $67 \%$ moneyness in the next column. $(-0.027, t=-3.08$ and $-0.023, t=-2.14)$. Consistent with our prediction, this means that there is no perfect overlap between the two measures; they capture distinct information

\footnotetext{
${ }^{13}$ Cheng and Farber $(2008,1234)$ report similar findings when they test the number of option grants.
} 
about risk-taking. CEOs' holding of exercisable options that are deep in-the-money may not reflect overinvestment to the extent it relates to excessive risk-taking in financing and financial reporting choices, as suggested by recent literature (see footnote 4). CEOs' holding of exercisable options that are deep in-the-money may even capture underinvestment to the extent it reflects equity overvaluation, as CEOs of firms with overvalued equity might reduce discretionary spending in $R \& D$, to inflate reported profits and keep the price high and rising (Efendi et al., 2007). At the same time, overinvestment in R\&D may not coincide with CEOs' holding of exercisable options that are deep in-themoney if the options in the CEOs' portfolios have not yet vested, or if overinvestment is unintentional or due to estimation error. The coefficient on the interaction term Moneyness $100^{*}$ RiskyR\&D and Moneyness67*RiskyR\&D in the next two columns are insignificant, indicating no incremental change in option grants for firms whose CEOs' hold exercisable options deep in-them money and overinvest in R\&D. Collectively the results in Table 4 suggest that neither of the two measures, CEOs' holding of exercisable options that are deep in-the-money and firms' excessive investment in $R \& D$, provide a comprehensive measure of excessive risk-taking. One implication of this finding is that in monitoring excessive risk-taking, compensation committees need to monitor both firm and director characteristics to detect deviation from optimal levels of equity incentives.

\subsection{The impact of aggressive reporting}

The results so far suggest that, on average, compensation committees are able to detect excessive risk-taking and respond by reducing future option grants. While this evidence is consistent with firms using option-based compensation effectively, it does not explain clear evidence of misaligned incentives evident in earnings restatements and numerous corporate failures, where the root cause was excessive risk-taking. We shed light into this puzzle by exploring the effect of aggressive reporting. Aggressive reporting raises the possibility that excessive risk-taking goes undetected or uncorrected for. If managers mask the outcomes of poorly performing risky projects or equity overvaluation through artificially inflated returns, they may lead compensation committees to raise the risk tolerance levels, preventing detection of excessive risk-taking. If stock option grants are not revised accordingly, executive pay carries on fueling the earnings management game (Jensen, 2005). 
To assess the impact of aggressive reporting, the first column of Table 5 reports the results of regressing $\Delta$ Options_Grants $\%_{t}$ on Aggressive_Reporting t-1 $_{-}$as an indicator of firms reporting excessively positive performance adjusted abnormal accruals in the last year. The coefficient on Aggressive_Reporting t-1 $_{1}$ is not significant, consistent with aggressive reporting not being factored in revisions of future option grants. The result is sustained once we add the two measures of excessive risk-taking in the next column. While the coefficients on Moneyness 100 and RiskyR\&D remain negative and significant $(-0.032, t=-3.07$ and $-0.022, t=-2.12)$, the coefficient on Aggressive_Reporting is insignificant. This evidence suggests that firms are not able to mitigate the agency problems related to earnings management in the design of option-based compensation.

To assess the effect of this deficiency on the boards' correction for excessive risktaking, we next report the results of regressive $\Delta$ Options_Grants $\%_{t}$ on the two measures of excessive risk-taking, the indicator of aggressive reporting and interaction terms (Columns 2-3). The coefficients on Moneyness 100 and RiskyR\&D remain negative and significant $(-0.033, t=-2.99$ and $-0.033, t=-2.40)$, indicating that CEOs exhibiting either type of risky behavior, moneyness in exercisable option holdings, or overinvestment in $\mathrm{R} \& \mathrm{D}$, without reporting aggressively, receive fewer option grants. Once excessive risk-taking is combined with aggressive reporting, however, efficiency in setting option-based compensation seems to fade away. The coefficient on Moneyness 100*Aggressive_Reporting is positive (yet not significant at conventional levels $0.015, t=0.58$ ), while RiskyR\&D*Aggressive_Reporting is positive and significant, outweighing the RiskyR\&D coefficient by itself $(0.058, t=1.99)$. Consistent with our second hypothesis, this means that aggressive reporting attenuates the association between excessive risk-taking and changes in option based compensation. To assess the extent of this attenuation, we repeat the regressions of $\Delta$ Options_Grants $\%_{t}$ on the two measures of excessive risk-taking separately clustering by Aggressive_Reporting. For firms engaging in aggressive reporting (Aggressive_Reporting=1,20\% of the sample), the coefficients on both Moneyness 100 and RiskyR $\& D$ are insignificant. The coefficients on Moneyness 100 and RiskyR\&D are negative and significant $(-0.031, t=-3.05$ and $-0.034, t=-2.99)$ only for remaining firms in the sample, consistent with excessive risk-taking being factored in revisions of future option grants only for firms not engaging in aggressive reporting. Collectively, the results of Table 5 
provide evidence in support of the damaging effect of aggressive reporting in masking true underlying risk and preventing its correction through option based compensation.

\subsection{Robustness tests}

We test the robustness of our results to alternative estimation methods, dependent variables, and measures of excessive risk.

\section{Alternative estimation methods}

Since our model is already in a change specification, following Cheng and Farber (2008), we present results using an OLS model with robust standard errors. When we further run a fixed effects model, and cluster our standard errors by both firm and year, our results show that CEOs' holding of exercisable options that are deep in-the-money continues to have a negative relationship with subsequent option grants, with $\operatorname{RiskyR} \& D$ marginally significant.

To control for the influence of outlying observations, we examine the models using robust re-weighted regressions, and the key inferences from all of the models remain unchanged.

\section{Alternative dependent variable}

Our results are presented using percentage change in the number of options granted as a dependent variable. We consider an alternative dependent variable based on the change in the dollar value of the options granted using the Black-Scholes method (Execucomp's OPTION_AWARDS_BLK_VALUE), scaled by total compensation (TDC1), following Cheng and Farber (2008). We document a reduction in the dollar value of option grants for firms overinvesting in $R \& D\left(R i s k y R \& D_{t-1}=1\right)$, consistent with the change in the number of options granted, but not for firms whose CEOs' hold exercisable options that are deep in-the-money (Moneyness $100_{t-1}=1$ ). The latter result may be due to the dollar value of option grants being mechanically associated with option moneyness embedded in Moneyness $100_{t-1}$. The percentage change in the number of option grants avoids this limitation and reflects more directly changes in the design of option-based compensation. The number of options granted is also a cleaner measure affording direct comparability to previous periods, since it can only be indirectly affected by other parameters which are used in stock option valuation (e.g. volatility, dividend yield, interest rates, current market price, time to maturity). 
Alternative measure to CEOs' holding of exercisable options that are deep in-the-money As an alternative measure of CEO overconfidence Malmendier and Tate (2005) and Campbell et al. (2010) use a construct based on the changes in the CEO's shareholdings during the past years. While net stock purchases might reflect CEOs' overconfidence, they do not subject the firm to the same potential risk as CEOs' holding of exercisable options, as managers share the risk of their actions with the shareholders. To this extent we believe that net stock purchases are a noisier measure of excessive risk-taking as it merely reflects excess risk that firm faces from an overconfident CEO. For consistency with prior literature, however, we repeat the regression results using a measure of net stock purchases.

We classify CEOs as making high "net stock purchases" if they have increased their stock ownership in a given year by at least 10\%, as long as this change is also in the top quintile of all CEOs. Similar to Malmendier and Tate (2005), we impose a minimum tenure of five years in the firm when using this measure. Our untabulated results show that CEOs that substantially increase their shareholdings in the firm are awarded fewer option grants, but that the effect is weaker, consistent with our argument that net stock purchases provide a noisier measure of excessive risk-taking.

\section{Conclusion}

In this paper, we examine whether compensation committees are able to respond to excessive risk-taking created by over-incentives from stock options, by reducing stock option-based compensation granted to CEOs. We build on prior work which links equity incentives with risk and incentives to misreport (Burns and Kedia, 2006; Efendi et al., 2007), and compensation committee responses to evidence of misreporting, in the form of earnings restatements (Cheng and Farber, 2008). Instead of earnings restatements, which are infrequent events and are only detectable after the fact, we focus on dynamically and more widely applicable evidence of excessive risk-taking, which compensation committees can deduce from observing CEOs' option holding behavior and firm's investment in $R \& D$.

Using a large panel of firms from 1994-2008, we find that compensation committees are indeed responsive to evidence of risk-taking, as measured by CEO failure to exercise exercisable stock options, and abnormally high levels of $\mathrm{R} \& \mathrm{D}$, and reduce stock option grants in subsequent periods. We find, however, that in firms which adopt 
aggressive financial reporting policies, measured using performance adjusted abnormal accruals, this responsiveness is weakened. This suggests that aggressive reporting is successful at shifting the acceptable risk appetite of the compensation committee towards a higher level before recontracting takes place. These findings hold after controlling for a number of firm- and director-specific characteristics, and using different econometric specifications. We find that revisions in stock option compensation are negatively associated with changes in the number of exercisable and unexercisable options, firm size, and returns.

We contribute to literature on factors affecting compensation contracts, in particular those which suggest sub-optimality, finding that excessive risk-taking is a contributing factor. We complement findings of Cheng and Farber (2008) and Core and Guay (1999) on responses to evidence of sub-optimality in compensation contracts. We also offer insights on the damaging effect of financial reporting choices in the design of CEOs' option based compensation. Our evidence suggests that that compensation committees should more carefully scrutinize the financial reporting choices of CEOs suspected of excessive risk-taking. Another implication of our findings is that compensation committees need to consider both CEO and firm characteristics in assessing excessive risk-taking, as both CEOs' holding of exercisable options that are deep in-the-money and overinvestment in $R \& D$ are not perfectly overlapping predictors of excess risk.

A limitation of our analysis is that compensation committees that observe high levels of non-exercise of stock options may believe that the CEO is sufficiently, but not necessarily overly incentivized. Without making assumptions about suboptimal actions that holding behavior may induce, the compensation committee may take the holding of in-the-money exercisable options as evidence that the CEO is sufficiently incentivized because he has chosen not to sell, and reduce subsequent option grants. Therefore behavioural judgements about risky actions associated with high option holding levels are not necessary to explain reduction in stock option grants. 
Appendix

Definition of variables in alphabetical order

\begin{tabular}{|c|c|}
\hline Variable & Description \\
\hline$A A$ & Abnormal accruals based on the Jones (1991) model. \\
\hline Aggressive_Reporting & $\begin{array}{l}\text { Dummy variable equal to } 1 \text { if the observation belongs to the top quintile of } \\
\text { performance adjusted abnormal accruals PAAA, } 0 \text { otherwise. }\end{array}$ \\
\hline$A R D$ & $\begin{array}{l}\text { Abnormal R\&D expense based on the models of Berger (1993) and Gunny } \\
\text { (2009). }\end{array}$ \\
\hline Assets & Average total assets of the current and last year. \\
\hline$B / M$ & Book-to-market ratio. \\
\hline CAPEX & Capital expenditure (excluding R\&D) divided by sales. \\
\hline CashCompensation & Salary and Bonus, scaled by Sales \\
\hline CashShortfall & $\begin{array}{l}\text { Cash flow shortfall calculated as common and preferred dividends plus cash } \\
\text { flow used in investment activities minus cash flows from operations all divided } \\
\text { by total assets }\end{array}$ \\
\hline ExcessiveRiskMeasure & Defined as Moneyness67, Moneynes 100, or RiskyR\&D, according to model \\
\hline Exercisable_Options & $\begin{array}{l}\text { Number of exercisable options owned by the CEO, scaled by shares } \\
\text { outstanding. }\end{array}$ \\
\hline FUNDS & $\begin{array}{l}\text { Proxy for the firm's pre-R\&D cash flow, defined as pre-tax income, plus } \\
\text { interest expense, plus the R\&D expense, plus depreciation divided by sales. }\end{array}$ \\
\hline Lev & Total debt divided by total assets. \\
\hline Moneyness & $\begin{array}{l}\text { Stock price divided by estimated exercise price of exercisable stock options, } \\
\text { less } 1 .\end{array}$ \\
\hline Moneyness 100 & $\begin{array}{l}\text { Dummy variable equal to } 1 \text { if the CEO holds exercisable options with a } \\
\text { moneyness of at least } 100 \% \text {, and has done so at least twice in the sample period, } \\
0 \text { otherwise. }\end{array}$ \\
\hline Moneyness67 & $\begin{array}{l}\text { Dummy variable equal to } 1 \text { if the CEO holds exercisable options with a } \\
\text { moneyness of at least } 67 \% \text {, and has done so at least twice in the sample period, } \\
0 \text { otherwise. }\end{array}$ \\
\hline NetOperatingLoss & Dummy variable equal to 1 if the firm reports operating losses, 0 otherwise. \\
\hline $\mathrm{NewCEO}$ & $\begin{array}{l}\text { Dummy variable equal to } 1 \text { if there is a change in CEO during the year, } 0 \\
\text { otherwise. }\end{array}$ \\
\hline Option_Grants\% & $\begin{array}{l}\text { Number of options granted during the year to the CEO, scaled by shares } \\
\text { outstanding. }\end{array}$ \\
\hline PAAA & $\begin{array}{l}\text { Performance adjusted abnormal accruals calculated by adjusting the abnormal } \\
\text { accrual estimate of each firm-year observation for the abnormal accrual estimate } \\
\text { of a matched firm based on current year return on assets, ROA, and industry. }\end{array}$ \\
\hline PastReturn & Accumulated monthly stock return for the last year. \\
\hline$P P E$ & Gross value of property, plant and equipment. \\
\hline$R D$ & R\&D expense divided by sales \\
\hline Return & Accumulated monthly stock return for the current year. \\
\hline RiskyR\&D & $\begin{array}{l}\text { Dummy variable equal to } 1 \text { if the observation belongs to the top quintile of } \\
\text { abnormal R\&D }(A R D), 0 \text { otherwise. }\end{array}$ \\
\hline$R O A$ & Profit before extraordinary items divided by average total assets. \\
\hline Shares_Own & Shares owned by the CEO, excluding options, scaled by shares outstanding \\
\hline Size & Natural log of sales revenue. \\
\hline$T A$ & $\begin{array}{l}\text { Total accruals measured as }(\triangle \mathrm{CA}-\triangle \mathrm{CL}-\triangle \mathrm{Cash}+\triangle \mathrm{STDEBT}-\mathrm{DEPN}) \text {, } \\
\text { where } \triangle C A=\text { change in current liabilities, } \triangle C \text { Cash }=\text { change in cash, } \triangle S T D E B T= \\
\text { change in debt in current liabilities, and DEPN is the depreciation and } \\
\text { amortization expense. }\end{array}$ \\
\hline$T O B I N Q$ & $\begin{array}{l}\text { Total market capitalization plus book value of preferred stock, plus long-term } \\
\text { debt, plus short-term debt all divided by total assets. }\end{array}$ \\
\hline Unexercisable_Options & $\begin{array}{l}\text { Number of unexercisable options owned by the CEO, scaled by shares } \\
\text { outstanding }\end{array}$ \\
\hline$\triangle A R$ & Change in accounts receivable. \\
\hline$\triangle R E V$ & Change in total revenue. \\
\hline oReturn & Standard deviation of monthly stock returns in the current year. \\
\hline
\end{tabular}




\section{References}

Agrawal, A., Mandelker, G.N., 1987. Managerial Incentives and Corporate Investment and Financing Decisions. Journal of Finance 42, 823-837.

Baber, W.R., Janakiraman, S.N., Kang, S.H., 1996. Investment Opportunities and the Structure of Executive Compensation. Journal of Accounting and Economics 21, 297-318.

Balachandran, S., Kogut, B., Harnal, H., 2010. The Probability of Default, Excessive Risk, and Executive Compensation: A Study of Financial Services Firms from 1995 to 2008. Working Paper, Columbia University.

Ben-David, I., Graham, J.R., Harvey, C.R., 2007. Managerial Overconfidence and Corporate Policies. Working Paper, Duke University.

Bereskin, F.L., Hsu, P.H., 2010. New Dogs New Tricks: CEO Turnover, CEO-Related Factors, and Innovation Performance. Working Paper, University of Delaware.

Berger, P.G., 1993. Explicit and Implicit Tax Effects of the R\&D Tax Credit. Journal of Accounting Research 31, 131-171.

Bergstresser, D., Philippon, T., 2006. CEO incentives and earnings management. Journal of Financial Economics 80, 511-529.

Brick, I.E., Palmon, O., Wald, J.K., 2006. CEO compensation, director compensation, and firm performance: Evidence of cronyism? Journal of Corporate Finance 12, 403-423.

Bryan, S., Hwang, L., Lilien, S., 2000. CEO Stock-Based Compensation: An Empirical Analysis of Incentive-Intensity, Relative Mix, and Economic Determinants. Journal of Business 73, 661-693.

Burns, N., Kedia, S., 2006. The impact of performance-based compensation on misreporting. Journal of Financial Economics 79, 35-67.

Bushman, R., Chen, Q., Engel, E., Smith, A., 2004. Financial accounting information, organizational complexity and corporate governance systems. Journal of Accounting and Economics 37, 167-201.

Campbell, T.C., Gallmeyer, M., Johnson, S.A., Rutherford, J., Stanley, B.W., 2010. CEO Optimism and Forced Turnover. Journal of Financial Economics, forthcoming.

Carter, M.E., Lynch, L.J., Tuna, I., 2007. The Role of Accounting in the Design of CEO Equity Compensation. Accounting Review 82, 327-357.

Chatterjee, A., Hambrick, D.C., 2007. It's All about Me: Narcissistic Chief Executive Officers and Their Effects on Company Strategy and Performance. Administrative Science Quarterly 52, 351-386.

Cheng, Q., Farber, D.B., 2008. Earnings Restatements, Changes in CEO Compensation, and Firm Performance. Accounting Review 83, 1217-1250.

Cheng, Q., Warfield, T.D., 2005. Equity Incentives and Earnings Management. Accounting Review 80, 441-476.

Cohen, D.A., Dey, A., Lys, T.Z., 2007. The Sarbanes Oxley Act of 2002: Implications for Compensation Contracts and Managerial Risk-Taking. Working Paper, Northwestern University.

Cohen, R.B., Hall, B.J., Viceira, L.M., 2000. Do Executive Stock Options Encourage Risk-Taking? Working Paper, Harvard Business School.

Coles, J.L., Daniel, N.D., Naveen, L., 2006. Managerial incentives and risk-taking. Journal of Financial Economics 79, 431-468.

Core, J., Guay, W., 1999. The use of equity grants to manage optimal equity incentive levels. Journal of Accounting and Economics 28, 151-184. 
Core, J., Guay, W., 2002. Estimating the Value of Employee Stock Option Portfolios and Their Sensitivities to Price and Volatility. Journal of Accounting Research 40, 613-630.

Cyert, R.M., Kang, S.H., Kumar, P., 2002. Corporate Governance, Takeovers, and TopManagement Compensation: Theory and Evidence. Management Science 48, 453469.

Davila, A., Penalva, F., 2006. Governance structure and the weighting of performance measures in CEO compensation. Review of Accounting Studies 11, 463-493.

Demsetz, H., Lehn, K., 1985. The Structure of Corporate Ownership: Causes and Consequences. Journal of Political Economy 93, 1155-1177.

Efendi, J., Srivastava, A., Swanson, E.P., 2007. Why do corporate managers misstate financial statements? The role of option compensation and other factors. Journal of Financial Economics 85, 667-708.

Ertrugul, M., Krishnan, K., 2011. Can CEO dismissals be proactive? Journal of Corporate Finance 17, 134-151.

Fama, E.F., French, K.R., 1997. Industry costs of equity. Journal of Financial Economics 43, 153-193.

Gaver, J., Gaver, K., 1993. Additional evidence on the association between the investment opportunity set and corporate financing, dividend, and compensation policies. Journal of Accounting and Economics 16, 125-160.

Grant, J., Markarian, G., Parbonetti, A., 2009. CEO Risk-Related Incentives and Income Smoothing. Contemporary Accounting Research 26, 1029-1065.

Guay, W.R., 1999. The sensitivity of CEO wealth to equity risk: an analysis of the magnitude and determinants - managerial behavior, agency costs, and ownership structure. Journal of Financial Economics 53, 43-71.

Gunny, K., 2009. The Relation between Earnings Management Using Real Activities Manipulation and Future Performance: Evidence from Meeting Earnings Benchmarks. Working Paper, University of Colorado at Boulder.

Hall, B.J., Liebman, J.B., 1998. Are CEOS Really Paid Like Bureaucrats? Quarterly Journal of Economics 113, 653-691.

Hanlon, M., Rajgopal, S., Shevlin, T., 2003. Are executive stock options associated with future earnings? Journal of Accounting and Economics 36, 3-43.

Himmelberg, C.P., Hubbard, G., Palia, D., 1999. Understanding the determinants of managerial ownership and the link between ownership and performance. Journal of Financial Economics 53, 353-384.

Himmelberg, C.P., Petersen, B.C., 1994. R \& D and Internal Finance: A Panel Study of Small Firms in High-Tech Industries. Review of Economics and Statistics 76, 3851 .

Hirshleifer, D.A., Low, A., Teoh, S.H., 2010. Are Overconfident CEOs Better Innovators. Working Paper, University of California, Irvine.

Hribar, P., Yang, H., 2010. Does CEO Overconfidence Affect Management Forecasting and Subsequent Earnings Management? Working Paper, University of Iowa.

Jensen, M., 1986. Agency costs of free cash flow, corporate finance, and takeovers American Economic Review 76, 323-329.

Jensen, M., 2005. Agency Costs of Overvalued Equity. Financial Management 34, 5-19.

Jensen, M., Murphy, K., 1990. Performance pay and top-management incentives. Journal of Political Economy 98, 225-264.

Jones, J.J., 1991. Earnings Management During Import Relief Investigations. Journal of Accounting Research 29, 193-228. 
Ju, N., Leland, H., Senbet, L.W., 2003. Options, Option Repricing and Severance Packages in Managerial Compensation: Their Effects on Corporate Investment Risk. Working Paper, University of Maryland.

Klassen, K.J., Mawani, A., 2000. The Impact of Financial and Tax Reporting Incentives on Option Grants to Canadian CEOs. Contemporary Accounting Research 17, 227-262.

Kothari, S.P., Leone, A.J., Wasley, C.E., 2005. Performance matched discretionary accrual measures. Journal of Accounting and Economics 39, 163-197.

Lambert, R.A., Larcker, D.F., 1987. An Analysis of the use of Accounting and Market Measures of Performance in Executive Compensation Contracts. Journal of Accounting Research 25, 85-127.

Laux, V., 2010. Executive Pay, Innovation, and Risk-Taking. Working Paper, University of Texas at Austin.

Malmendier, U., Tate, G., 2005. CEO Overconfidence and Corporate Investment. Journal of Finance 60, 2661-2700.

Malmendier, U., Tate, G., 2008. Who makes acquisitions? CEO overconfidence and the market's reaction. Journal of Financial Economics 89, 20-43.

Malmendier, U., Tate, G., Yan, J., 2010. Managerial Beliefs and Corporate Financial Policies. Working Paper, University of California, Berkeley.

Matsunaga, S., 1995. The Effects of Financial Reporting Costs on the Use of Employee Stock Options. Accounting Review 70, 1-26.

Murphy, K., 1999. Executive compensation. In: Ashenfelter O \& Card D (eds.) In Handbook of Labor Economics. North Holland, Amsterdam, the Netherlands.

Rajgopal, S., Shevlin, T., 2002. Empirical evidence on the relation between stock option compensation and risk taking. Journal of Accounting and Economics 33, 145-171.

Schrand, C.M., Zechman, S.L.C., 2008. Executive Overconfidence and the Slippery Slope to Fraud. Working Paper, University of Pennsylvania.

Smith, C.W., Jr., Watts, R.L., 1992. The Investment Opportunity Set and Corporate Financing, Dividend, and Compensation Policies. Journal of Financial Economics 32, 263-292.

Sudarsanam, S., Huang, J., 2007. Executive compensation and managerial overconfidence: impact on risk taking and shareholder value in corporate acquisitions. In: Gregoriou GN \& Renneboog L (eds.) International mergers and acquisitions activity since 1990: recent research and quantitative analysis. Elsevier, Inc., Burlington, MA.

Yermack, D., 1995. Do corporations award CEO stock options effectively? Journal of Financial Economics 39, 237-269. 


\section{Table 1: Descriptive Statistics}

\begin{tabular}{|c|c|c|c|c|c|c|c|c|}
\hline Variable & $\mathbf{N}$ & Mean & Min & Q1 & Median & Q3 & Max & S.D. \\
\hline$\triangle \#$ Option\% & 11,789 & -0.021 & -4.922 & -0.070 & 0.000 & 0.051 & 4.768 & 0.465 \\
\hline Moneyness $100_{t-1}$ & 11,789 & 0.263 & 0.000 & 0.000 & 0.000 & 1.000 & 1.000 & 0.440 \\
\hline Moneyness67 ${ }_{t-1}$ & 11,789 & 0.382 & 0.000 & 0.000 & 0.000 & 1.000 & 1.000 & 0.486 \\
\hline$R i s k y R \& D_{t-1}$ & 11,789 & 0.200 & 0.000 & 0.000 & 0.000 & 0.000 & 1.000 & 0.400 \\
\hline Aggressive_Reporting ${ }_{t-1}$ & 11,789 & 0.199 & 0.000 & 0.000 & 0.000 & 0.000 & 1.000 & 0.399 \\
\hline$\Delta$ CashCompensation $_{t-1}$ & 11,789 & 0.000 & -0.081 & 0.000 & 0.000 & 0.000 & 0.058 & 0.002 \\
\hline$\Delta$ Shares_Own $n_{t-1}$ & 11,789 & -0.173 & -24.942 & -0.076 & 0.000 & 0.044 & 23.952 & 1.788 \\
\hline $\begin{array}{l}\Delta \text { Exercisable }_{-} \\
\text {Options }_{t-1}\end{array}$ & 11,789 & 0.072 & -4.285 & -0.018 & 0.061 & 0.214 & 4.761 & 0.501 \\
\hline $\begin{array}{l}\Delta \text { Unexercisable }_{-} \\
\text {Options }_{t-1}\end{array}$ & 11,789 & -0.020 & -4.829 & -0.130 & -0.003 & 0.069 & 4.504 & 0.453 \\
\hline NewCEO ${ }_{t-1}$ & 11,789 & 0.114 & 0.000 & 0.000 & 0.000 & 0.000 & 1.000 & 0.318 \\
\hline$\Delta$ Size $_{t-1}$ & 11,789 & 0.107 & -3.656 & 0.015 & 0.091 & 0.188 & 2.207 & 0.236 \\
\hline$\Delta B / M_{t-1}$ & 11,789 & 0.006 & -13.755 & -0.079 & 0.002 & 0.083 & 16.350 & 0.435 \\
\hline NetOperatingLoss $_{t-1}$ & 11,789 & 0.087 & 0.000 & 0.000 & 0.000 & 0.000 & 1.000 & 0.283 \\
\hline$\Delta$ CashShortfall $_{t-1}$ & 11,789 & 0.004 & -2.411 & -0.073 & 0.001 & 0.077 & 3.078 & 0.198 \\
\hline$\Delta L e v_{t-1}$ & 11,789 & 0.001 & -1.181 & -0.031 & -0.002 & 0.021 & 1.523 & 0.088 \\
\hline$\Delta$ CurrentReturn $_{t-1}$ & 11,789 & -0.025 & -15.735 & -0.363 & -0.015 & 0.330 & 11.020 & 0.987 \\
\hline$\Delta$ PastReturn ${ }_{t-1}$ & 11,789 & -0.037 & -17.122 & -0.384 & -0.024 & 0.335 & 12.141 & 1.082 \\
\hline$\Delta \sigma$ Return $_{t-1}$ & 11,789 & -0.003 & -2.623 & -0.028 & -0.002 & 0.022 & 2.643 & 0.070 \\
\hline$\Delta R \& D_{t-1}$ & 11,789 & -0.002 & -4.074 & 0.000 & 0.000 & 0.000 & 2.122 & 0.113 \\
\hline$\triangle C A P E X_{t-1}$ & 11,789 & -0.003 & -1.341 & -0.012 & -0.001 & 0.009 & 1.261 & 0.044 \\
\hline $\begin{array}{l}\text { RiskyR\&D } D_{t-1} * \\
\text { Moneyness } 100_{t-1}\end{array}$ & 11,789 & 0.067 & 0.000 & 0.000 & 0.000 & 0.000 & 1.000 & 0.250 \\
\hline $\begin{array}{l}\text { RiskyR } \& D_{t-1} * \\
\text { Moneyness } 67_{t-1}\end{array}$ & 11,789 & 0.091 & 0.000 & 0.000 & 0.000 & 0.000 & 1.000 & 0.287 \\
\hline $\begin{array}{l}\text { Moneyness } 100_{t-1} * \\
\text { Aggressive_Reporting }\end{array}$ & 11,789 & 0.055 & 0.000 & 0.000 & 0.000 & 0.000 & 1.000 & 0.228 \\
\hline $\begin{array}{l}\text { RiskyR\&D_t-1 * } \\
\text { Aggressive_Reporting }\end{array}$ & 11,789 & 0.039 & 0.000 & 0.000 & 0.000 & 0.000 & 1.000 & 0.194 \\
\hline
\end{tabular}

This table reports descriptive statistics for our dependent variable, $\triangle \#$ Option $\%$, key variables of interest measuring firm risk, changes in director characteristics and holdings, and changes in firm characteristics, such as firm performance, and leverage, on our final regression sample. All variables are as defined in the Appendix, and are presented in the form used in the regression model. Moneyness $100_{t-1}$, Moneyness67 ${ }_{t-1}$, RiskyR\&D ${ }_{t-1}$, Aggressive_Reporting ${ }_{t-1}$, NewCEO $_{t-1}$, NetOperatingLoss ${ }_{t-1}$ and their resulting interaction variables are indicator variables, with the proportion of observations=1 shown by the Mean column. 
Table 2: Correlation Matrix of Variables

\begin{tabular}{|c|c|c|c|c|c|c|c|c|c|c|c|c|c|c|c|c|c|c|c|c|}
\hline & 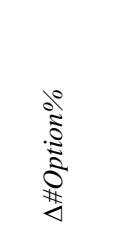 & 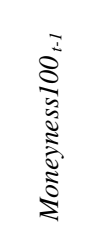 & 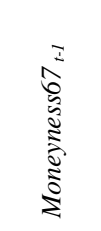 & 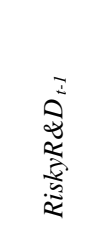 & 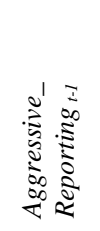 & 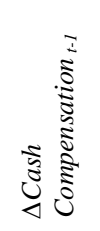 & 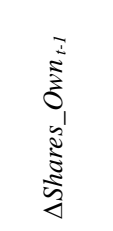 & 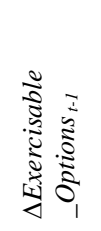 & 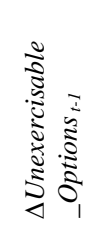 & 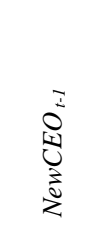 & 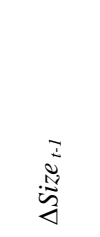 & $\stackrel{j}{\beth}$ & 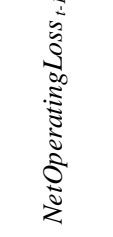 & 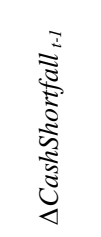 & $\frac{\bar{z}}{\bar{y}}$ & 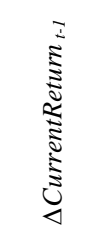 & 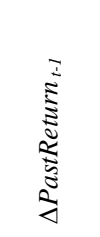 & 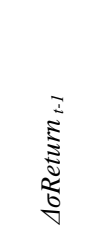 & 文 & 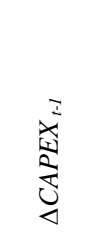 \\
\hline$\triangle \#$ Option\% & 1 & -0.010 & -0.010 & -0.018 & 0.009 & -0.027 & 0.003 & -0.013 & -0.410 & -0.061 & -0.002 & 0.024 & -0.012 & 0.009 & -0.008 & -0.049 & -0.011 & 0.011 & 0.009 & 0.003 \\
\hline Moneyness $100_{t-1}$ & -0.018 & 1 & 0.760 & 0.082 & 0.013 & -0.036 & -0.014 & -0.042 & -0.037 & -0.061 & 0.247 & -0.039 & -0.092 & -0.052 & -0.023 & 0.008 & 0.012 & 0.018 & -0.009 & 0.035 \\
\hline Moneyness $67_{t-1}$ & -0.015 & 0.760 & 1 & 0.073 & 0.014 & -0.043 & -0.012 & -0.037 & -0.038 & -0.066 & 0.254 & -0.053 & -0.115 & -0.050 & -0.029 & 0.014 & 0.022 & 0.012 & -0.015 & 0.038 \\
\hline$R i s k y R \& D_{t-1}$ & -0.029 & 0.082 & 0.073 & 1 & -0.004 & 0.027 & -0.008 & 0.021 & -0.018 & 0.000 & -0.026 & -0.003 & 0.124 & 0.015 & -0.003 & -0.001 & -0.013 & -0.017 & 0.094 & -0.039 \\
\hline Aggressive_Reporting ${ }_{t-1}$ & 0.007 & 0.013 & 0.014 & -0.004 & 1 & -0.019 & -0.001 & 0.000 & -0.016 & -0.001 & 0.011 & 0.022 & 0.012 & 0.025 & 0.116 & -0.018 & -0.013 & 0.006 & -0.007 & 0.004 \\
\hline$\Delta$ CashCompensation $_{t-1}$ & -0.001 & -0.099 & -0.100 & 0.007 & -0.031 & 1 & -0.007 & 0.035 & 0.053 & 0.026 & -0.259 & -0.001 & -0.057 & 0.044 & -0.047 & 0.048 & -0.048 & -0.021 & 0.541 & -0.001 \\
\hline$\Delta$ Shares_Own $n_{t-1}$ & 0.015 & -0.112 & -0.099 & -0.035 & -0.024 & 0.108 & 1 & 0.062 & -0.041 & -0.136 & -0.041 & -0.007 & -0.004 & 0.000 & 0.022 & 0.026 & -0.001 & -0.007 & -0.002 & 0.009 \\
\hline $\begin{array}{l}\Delta \text { Exercisable }_{-} \\
\text {Options }_{t-1}\end{array}$ & -0.032 & -0.073 & -0.064 & 0.022 & 0.018 & 0.055 & 0.135 & 1 & -0.141 & -0.185 & -0.075 & 0.039 & 0.017 & 0.022 & 0.006 & 0.002 & -0.012 & -0.033 & 0.002 & -0.017 \\
\hline $\begin{array}{l}\text { DUnexercisable } \\
\text { Options } \text { t }_{t-1}\end{array}$ & -0.286 & -0.072 & -0.074 & -0.027 & -0.025 & 0.083 & 0.037 & -0.154 & 1 & 0.136 & -0.053 & -0.003 & 0.000 & 0.017 & 0.022 & 0.050 & -0.026 & 0.025 & 0.001 & -0.016 \\
\hline NewCEO $O_{t-1}$ & -0.039 & -0.061 & -0.066 & 0.000 & -0.001 & -0.010 & -0.165 & -0.208 & 0.116 & 1 & -0.053 & -0.016 & 0.029 & 0.022 & 0.003 & 0.034 & -0.010 & 0.007 & 0.004 & -0.009 \\
\hline$\Delta$ Size $_{t-1}$ & -0.020 & 0.317 & 0.325 & 0.011 & 0.021 & -0.307 & -0.145 & -0.107 & -0.087 & -0.058 & 1 & -0.015 & -0.184 & -0.129 & 0.041 & -0.069 & 0.146 & 0.015 & -0.230 & 0.073 \\
\hline$\Delta B / M_{t-l}$ & 0.053 & -0.118 & -0.150 & 0.020 & 0.048 & -0.172 & 0.012 & 0.063 & -0.016 & -0.025 & -0.029 & 1 & -0.016 & 0.055 & -0.074 & -0.305 & 0.036 & 0.006 & 0.023 & -0.016 \\
\hline NetOperatingLoss t-I & -0.030 & -0.092 & -0.115 & 0.124 & 0.012 & 0.028 & -0.029 & 0.048 & -0.005 & 0.029 & -0.177 & 0.003 & 1 & 0.073 & 0.075 & -0.001 & -0.054 & 0.008 & -0.029 & -0.044 \\
\hline$\Delta$ CashShortfall $_{t-1}$ & 0.010 & -0.064 & -0.062 & 0.013 & 0.064 & -0.032 & 0.004 & 0.040 & 0.016 & 0.010 & -0.133 & 0.088 & 0.067 & 1 & -0.126 & -0.068 & -0.085 & 0.020 & 0.077 & -0.145 \\
\hline$\Delta L e v_{t-1}$ & 0.019 & -0.032 & -0.038 & 0.001 & 0.139 & -0.123 & 0.052 & 0.051 & 0.033 & 0.008 & 0.013 & 0.022 & 0.092 & -0.070 & 1 & -0.064 & -0.047 & 0.038 & 0.023 & 0.033 \\
\hline$\Delta$ CurrentReturn $_{t-1}$ & -0.050 & 0.009 & 0.023 & -0.003 & -0.021 & 0.217 & -0.010 & -0.037 & 0.048 & 0.030 & -0.042 & -0.639 & 0.013 & -0.049 & -0.092 & 1 & -0.487 & 0.104 & -0.036 & -0.070 \\
\hline$\Delta$ PastReturn $_{t-I}$ & 0.011 & 0.023 & 0.037 & 0.002 & -0.012 & -0.020 & -0.011 & -0.021 & -0.031 & -0.019 & 0.118 & 0.066 & -0.052 & -0.084 & -0.065 & -0.468 & 1 & -0.052 & -0.054 & 0.131 \\
\hline$\Delta \sigma$ Return $_{t-1}$ & 0.017 & 0.017 & 0.011 & -0.022 & 0.010 & -0.073 & 0.017 & -0.035 & 0.035 & 0.002 & 0.018 & 0.019 & -0.003 & 0.022 & 0.059 & -0.006 & -0.029 & 1 & -0.008 & -0.029 \\
\hline$\Delta R \& D_{t-1}$ & 0.002 & -0.006 & -0.010 & 0.143 & -0.022 & 0.012 & 0.022 & 0.027 & 0.014 & -0.005 & -0.214 & 0.069 & 0.049 & 0.091 & 0.071 & -0.061 & -0.057 & 0.019 & 1 & 0.010 \\
\hline$\triangle C A P E X_{t-1}$ & 0.006 & 0.056 & 0.072 & -0.054 & 0.014 & -0.051 & -0.002 & -0.022 & -0.038 & -0.016 & 0.132 & -0.057 & -0.056 & -0.174 & 0.003 & -0.078 & 0.139 & -0.005 & -0.011 & 1 \\
\hline
\end{tabular}

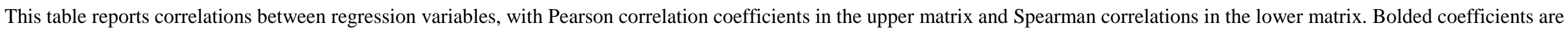

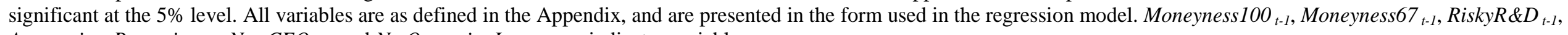
Aggressive_Reporting $_{t-1}$, NewCEO $_{t-1}$, and NetOperatingLoss $s_{t-1}$ are indicator variables. 


\section{Table 3: Impact of excessive risk-taking on changes in CEO option-based compensation}

This table reports regression results of the following equation:

$\Delta$ Options_Grants $\%_{i t}=a_{0}+a_{1}$ Excess_Risk $_{i, t-1}+\beta$ Controls $_{i, t-1}+$ YearDummies $+\varepsilon_{i t}$

$\Delta$ Options_Grants $\%_{i t}$ is changes in option grants (number of shares) scaled by shares outstanding, in percent. Excess_Risk is the moneyness in CEOs' stock option holdings and is measured through Moneyness $100_{t-1}$ or Moneyness67 $7_{t-1}$. Moneyness $100_{t-1}$ indicates directors holding exercisable options that are at least $100 \%$ in the money. Moneyness $67_{t-1}$ indicates directors holding exercisable options that are at least $67 \%$ in the money. Risky_R\&D indicates firms overinvesting in $\mathrm{R} \& \mathrm{D}$, i.e. classified in the top quintile of abnormal R\&D expense. Our sample consists of 11,789 observations from 1,786 U.S. firms from 1994-2008. The Appendix provides detailed definitions of all variables.

\begin{tabular}{|c|c|c|c|c|}
\hline Variables & $\begin{array}{l}\text { Predicted } \\
\text { Sign }\end{array}$ & $\begin{array}{c}(1) \\
\text { Coefficient } \\
t \text {-statistic } \\
\end{array}$ & $\begin{array}{c}(2) \\
\text { Coefficient } \\
t \text {-statistic }\end{array}$ & $\begin{array}{c}(3) \\
\text { Coefficient } \\
t \text {-statistic }\end{array}$ \\
\hline Intercept & & $\begin{array}{r}0.027 \\
(1.50)\end{array}$ & $\begin{array}{c}0.029 \\
(1.63)\end{array}$ & $\begin{array}{c}0.022 \\
(1.23)\end{array}$ \\
\hline Moneyness $100_{t-1}$ & - & $\begin{array}{l}-0.032 * * * \\
(-3.30)\end{array}$ & & \\
\hline Moneyness67 $7_{t-1}$ & - & & $\begin{array}{l}-0.028 * * * \\
(-3.32)\end{array}$ & \\
\hline$R i s k y R \& D_{t-1}$ & & & & $\begin{array}{l}-0.026 * * \\
(-2.44)\end{array}$ \\
\hline$\Delta$ CashCompensation $_{t-1}$ & \pm & $\begin{array}{l}-2.549 \\
(-0.59)\end{array}$ & $\begin{array}{l}-2.601 \\
(-0.60)\end{array}$ & $\begin{array}{l}-2.677 \\
(-0.62)\end{array}$ \\
\hline$\Delta$ Shares_Own & - & $\begin{array}{l}-0.004 \\
(-1.08)\end{array}$ & $\begin{array}{l}-0.004 \\
(-1.07)\end{array}$ & $\begin{array}{l}-0.004 \\
(-1.06)\end{array}$ \\
\hline$\Delta$ Exercisable_Options $s_{t-1}$ & - & $\begin{array}{l}-0.075 * * * \\
(-4.04)\end{array}$ & $\begin{array}{l}-0.075^{* * *} \\
(-4.02)\end{array}$ & $\begin{array}{l}-0.074 * * * \\
(-3.96)\end{array}$ \\
\hline$\Delta$ Unexercisable_Options $_{t-1}$ & - & $\begin{array}{l}-0.439 * * * \\
(-17.69)\end{array}$ & $\begin{array}{l}-0.439 * * * \\
(-17.69)\end{array}$ & $\begin{array}{l}-0.438 * * * \\
(-17.65)\end{array}$ \\
\hline$N e w C E O_{t-1}$ & - & $\begin{array}{l}-0.034 * \\
(-1.96)\end{array}$ & $\begin{array}{l}-0.034 * * \\
(-1.96)\end{array}$ & $\begin{array}{l}-0.031 * \\
(-1.81)\end{array}$ \\
\hline$\Delta$ Size $_{t-1}$ & + & $\begin{array}{l}-0.071 * * \\
(-2.46)\end{array}$ & $\begin{array}{l}-0.072 * * \\
(-2.48)\end{array}$ & $\begin{array}{l}-0.085^{* * * *} \\
(-3.03)\end{array}$ \\
\hline$\Delta B / M_{t-1}$ & - & $\begin{array}{c}0.008 \\
(0.42)\end{array}$ & $\begin{array}{c}0.007 \\
(0.41)\end{array}$ & $\begin{array}{c}0.009 \\
(0.48)\end{array}$ \\
\hline NetOperatingLoss $_{t-1}$ & + & $\begin{array}{l}-0.027 \\
(-1.37)\end{array}$ & $\begin{array}{l}-0.028 \\
(-1.43)\end{array}$ & $\begin{array}{l}-0.020 \\
(-1.04)\end{array}$ \\
\hline$\Delta$ CashShortfall $_{t-1}$ & + & $\begin{array}{c}0.014 \\
(0.51)\end{array}$ & $\begin{array}{c}0.014 \\
(0.53)\end{array}$ & $\begin{array}{c}0.015 \\
(0.57)\end{array}$ \\
\hline$\Delta L e v_{t-1}$ & - & $\begin{array}{l}-0.040 \\
(-0.60)\end{array}$ & $\begin{array}{l}-0.040 \\
(-0.61)\end{array}$ & $\begin{array}{l}-0.035 \\
(-0.53)\end{array}$ \\
\hline$\Delta$ Return $_{t-1}$ & \pm & $\begin{array}{l}-0.026 * * * \\
(-3.28)\end{array}$ & $\begin{array}{l}-0.025 * * * \\
(-3.27)\end{array}$ & $\begin{array}{l}-0.026 * * * \\
(-3.27)\end{array}$ \\
\hline$\Delta$ PastReturn $_{t-1}$ & \pm & $\begin{array}{l}-0.021 * * * \\
(-3.03)\end{array}$ & $\begin{array}{l}-0.021 * * * \\
(-3.00)\end{array}$ & $\begin{array}{l}-0.021 \text { *** } \\
(-2.97)\end{array}$ \\
\hline$\Delta \sigma$ Return $_{t-1}$ & + & $\begin{array}{c}0.074 \\
(0.99)\end{array}$ & $\begin{array}{c}0.073 \\
(0.99)\end{array}$ & $\begin{array}{c}0.072 \\
(0.97)\end{array}$ \\
\hline$\Delta R \& D_{t-1}$ & + & $\begin{array}{l}0.010 \\
(0.18)\end{array}$ & $\begin{array}{c}0.010 \\
(0.18)\end{array}$ & $\begin{array}{c}0.015 \\
(0.27)\end{array}$ \\
\hline$\triangle C A P E X_{t-1}$ & - & $\begin{array}{r}0.007 \\
(0.08)\end{array}$ & $\begin{array}{c}0.007 \\
(0.07)\end{array}$ & $\begin{array}{l}-0.006 \\
(-0.06)\end{array}$ \\
\hline Year Dummies & & YES & YES & YES \\
\hline Observations & & 11,789 & 11,789 & 11,789 \\
\hline Number of firms & & 1,786 & 1,786 & 1,786 \\
\hline R-Square & & 0.1872 & 0.1872 & 0.1868 \\
\hline Adjusted R-square & & 0.1851 & 0.1851 & 0.1848 \\
\hline
\end{tabular}

$t$-statistics in parentheses $* * * \mathrm{p}<0.01, * * \mathrm{p}<0.05, * \mathrm{p}<0.10$. Year dummies are omitted for brevity. 
The equations have been estimated using a pooled OLS model with robust standard errors. Our key inferences remain after clustering by both firm and year, or using a fixed-effects model. 


\section{Table 4: CEOs' holding of deep in-the-money exercisable options and overinvestment in $R \& D$}

This table reports regression results of the following equation:

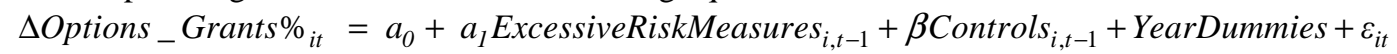

$\Delta$ Options_Grants $\%_{i t}$ is changes in option grants (number of shares) scaled by shares outstanding, in percent. Excess_Risk is the moneyness in CEOs' stock option holdings and is measured through Moneyness $100_{t-1}$ or Moneyness67 6 t-1. Moneyness $100_{t-1}$ indicates directors holding exercisable options that are at least $100 \%$ in the money. Moneyness $67_{t-1}$ indicates directors holding exercisable options that are at least $67 \%$ in the money. Risky_R\&D indicates firms overinvesting in $R \& D$, i.e. classified in the top quintile of abnormal R\&D expense. Our sample consists of 11,789 observations from 1,786 U.S. firms from 19942008. The Appendix provides detailed definitions of all variables.

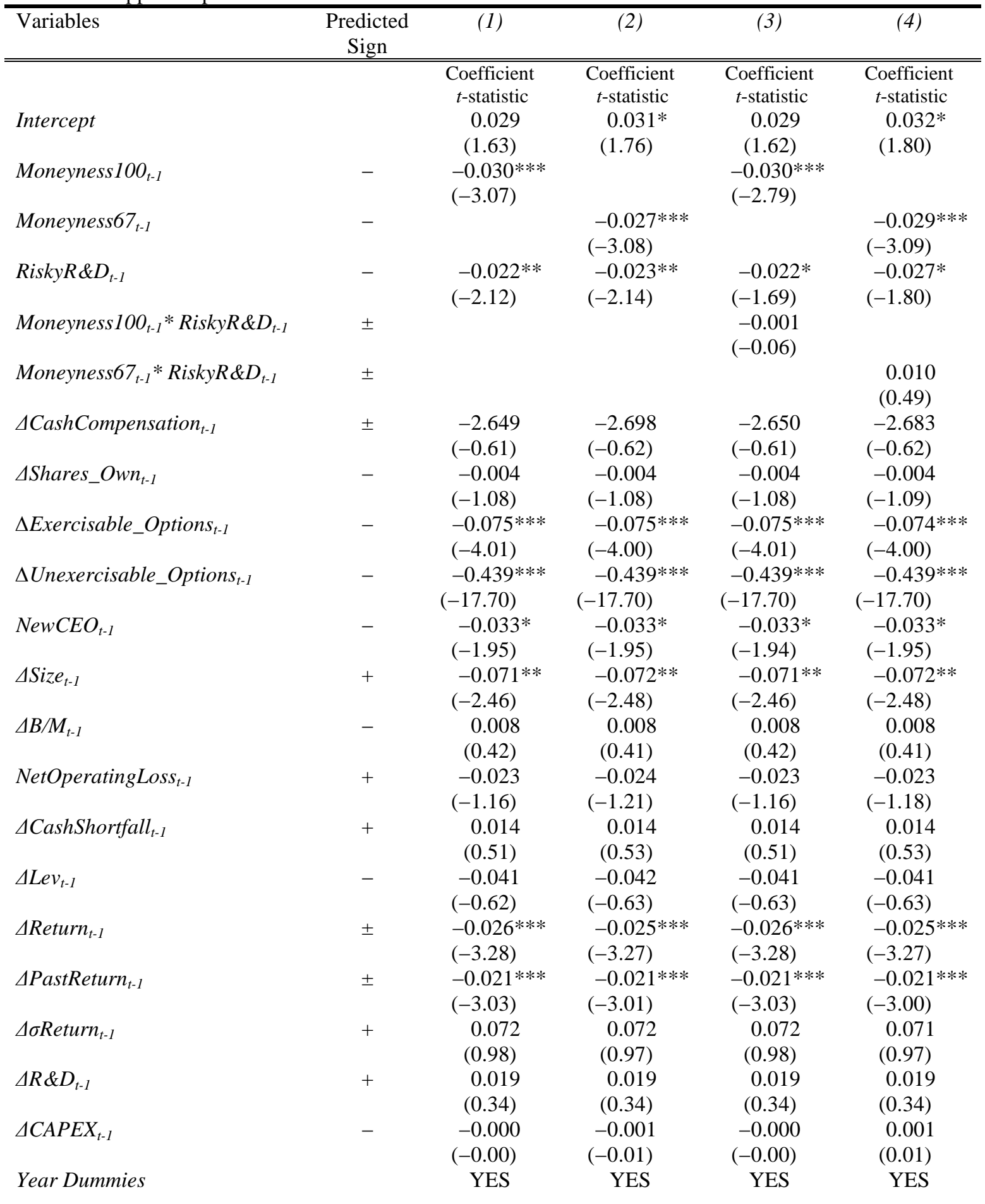




$\begin{array}{lcccc}\text { Observations } & 11,789 & 11,789 & 11,789 & 11,789 \\ \text { Number of firms } & 1,786 & 1,786 & 1,786 & 1,786 \\ \text { R-square } & 0.1876 & 0.1875 & 0.1876 & 0.1876 \\ \text { Adjusted R-square } & 0.1854 & 0.1854 & 0.1854 & 0.1853\end{array}$

$t$-statistics in parentheses $* * * \mathrm{p}<0.01, * * \mathrm{p}<0.05, * \mathrm{p}<0.10$. Year dummies are omitted for brevity. The equations have been estimated using a pooled OLS model with robust standard errors. Our key inferences remain after clustering by both firm and year, or using a fixed-effects model. 


\section{Table 5: Excessive risk-taking, aggressive reporting and changes in CEO option based compensation}

This table reports regression results of the following equation:

OOptions_Grants $_{i t}=a_{0}+a_{1}$ ExcessiveRiskMeasures $_{i, t-1}+a_{2}$ Aggressive $_{-}$Reporting $_{i, t-1}$

$$
+a_{3} \text { Excess_Risk }_{i, t-1} \times \text { Aggressive _ Reporting }_{i, t-1}+\beta \text { Controls }_{i, t-1}+\text { YearDummies }+\varepsilon_{i t}
$$

$\Delta$ Options_Grants $\%_{i t}$ is changes in option grants (number of shares) scaled by total shares outstanding, in percent. Excess_Risk is the moneyness in CEOs' stock option holdings and is measured as Moneyness100 t-1 or Moneyness67 ${ }_{t-1}$. Moneyness $100_{t-1}$ indicates directors holding exercisable options that are at least $100 \%$ in the money. Moneyness67 indicates directors holding exercisable options that are at least $67 \%$ in the money. Risky_R\&D indicates firms overinvesting in R\&D, i.e. classified in the top quintile of abnormal R\&D expense. Aggressive_Reporting indicates firms in the top quintile of abnormal performance adjusted discretionary accruals. Our sample consists of 11,789 observations from 1,786 U.S. firms from 1994-2008. The Appendix provides detailed definitions of all variables.

\begin{tabular}{|c|c|c|c|c|c|c|}
\hline Variables & $\begin{array}{l}\text { Predicted } \\
\text { Sign }\end{array}$ & $\begin{array}{c}(1) \\
\text { Coefficient } \\
t \text {-statistic }\end{array}$ & $\begin{array}{c}(2) \\
\text { Coefficient } \\
t \text {-statistic }\end{array}$ & $\begin{array}{c}(3) \\
\text { Coefficient } \\
t \text {-statistic }\end{array}$ & $\begin{array}{c}(4) \\
\text { Coefficient } \\
t \text {-statistic } \\
\text { Aggressive_ } \\
\text { Reporting }=1\end{array}$ & $\begin{array}{c}(5) \\
\text { Coefficient } \\
t \text {-statistic } \\
\text { Aggressive_ } \\
\text { Reporting= } \\
0\end{array}$ \\
\hline Intercept & & $\begin{array}{l}0.019 \\
(1.05)\end{array}$ & $\begin{array}{l}0.029 \\
(1.61)\end{array}$ & $\begin{array}{l}0.032 * \\
(1.77)\end{array}$ & $\begin{array}{l}0.005 \\
(0.13)\end{array}$ & $\begin{array}{l}0.038^{*} \\
(1.90)\end{array}$ \\
\hline Aggressive_Reporting $_{t-1}$ & - & $\begin{array}{l}-0.000 \\
(-0.04)\end{array}$ & $\begin{array}{c}0.000 \\
(0.01)\end{array}$ & $\begin{array}{l}-0.015 \\
(-1.21)\end{array}$ & & \\
\hline Moneyness $100_{t-1}$ & - & & $\begin{array}{l}-0.030 * * * \\
(-3.07)\end{array}$ & $\begin{array}{l}-0.033 * * * \\
(-2.99)\end{array}$ & $\begin{array}{l}-0.021 \\
(-0.83)\end{array}$ & $\begin{array}{l}-0.031 * * * \\
(-3.05)\end{array}$ \\
\hline$R i s k y R \& D_{t-1}$ & - & & $\begin{array}{l}-0.022 * * \\
(-2.12)\end{array}$ & $\begin{array}{l}-0.033^{* *} \\
(-2.40)\end{array}$ & $\begin{array}{c}0.026 \\
(0.98)\end{array}$ & $\begin{array}{l}-0.034 * * * \\
(-2.99)\end{array}$ \\
\hline $\begin{array}{l}\text { Moneyness } 100_{t-1} * \\
\text { RiskyR\&D } D_{t-1}\end{array}$ & \pm & & & $\begin{array}{l}-0.002 \\
(-0.09)\end{array}$ & & \\
\hline $\begin{array}{l}\text { Moneyness100 }{ }_{t-1} * \\
\text { Aggressive_Reporting }{ }_{t-1} \\
\text { RiskyR\&D } D_{t-1} * \\
\text { Aggressive_Reporting }\end{array}$ & + & & & $\begin{array}{l}0.015 \\
(0.58) \\
0.058^{* *} \\
(1.99)\end{array}$ & & \\
\hline$\Delta$ CashCompensation $_{t-1}$ & \pm & $\begin{array}{l}-2.566 \\
(-0.59)\end{array}$ & $\begin{array}{l}-2.648 \\
(-0.61)\end{array}$ & $\begin{array}{l}-2.608 \\
(-0.60)\end{array}$ & $\begin{array}{l}-0.369 \\
(-0.04)\end{array}$ & $\begin{array}{l}-4.269 \\
(-0.90)\end{array}$ \\
\hline$\Delta$ Shares_Own & - & $\begin{array}{l}-0.004 \\
(-1.05)\end{array}$ & $\begin{array}{l}-0.004 \\
(-1.08)\end{array}$ & $\begin{array}{l}-0.004 \\
(-1.09)\end{array}$ & $\begin{array}{l}-0.009 \\
(-0.88)\end{array}$ & $\begin{array}{l}-0.002 \\
(-0.71)\end{array}$ \\
\hline$\Delta$ Exercisable_Options ${ }_{t-1}$ & - & $\begin{array}{l}-0.074 * * * \\
(-3.98)\end{array}$ & $\begin{array}{l}-0.075^{* * *} \\
(-4.01)\end{array}$ & $\begin{array}{l}-0.075 * * * \\
(-4.02)\end{array}$ & $\begin{array}{l}-0.039 \\
(-1.14)\end{array}$ & $\begin{array}{l}-0.087 * * * \\
(-4.00)\end{array}$ \\
\hline$\Delta$ Unexercisable_Options $_{t-1}$ & - & $\begin{array}{l}-0.438 * * * \\
(-17.62)\end{array}$ & $\begin{array}{l}-0.439 * * * \\
(-17.68)\end{array}$ & $\begin{array}{l}-0.439 * * * \\
(-17.71)\end{array}$ & $\begin{array}{l}-0.369 * * * \\
(-6.90)\end{array}$ & $\begin{array}{l}-0.460 * * * \\
(-16.77)\end{array}$ \\
\hline$N e w C E O_{t-1}$ & - & $\begin{array}{l}-0.031 * \\
(-1.82)\end{array}$ & $\begin{array}{l}-0.033^{*} \\
(-1.95)\end{array}$ & $\begin{array}{l}-0.033^{*} \\
(-1.94)\end{array}$ & $\begin{array}{l}-0.033 \\
(-0.76)\end{array}$ & $\begin{array}{l}-0.034^{*} \\
(-1.85)\end{array}$ \\
\hline$\Delta$ Size $_{t-1}$ & + & $\begin{array}{l}-0.086 * * * \\
(-3.06)\end{array}$ & $\begin{array}{l}-0.071 * * \\
(-2.46)\end{array}$ & $\begin{array}{l}-0.071 * * \\
(-2.43)\end{array}$ & $\begin{array}{l}-0.002 \\
(-0.03)\end{array}$ & $\begin{array}{l}-0.104 * * * \\
(-3.68)\end{array}$ \\
\hline$\Delta B / M_{t-1}$ & - & $\begin{array}{r}0.009 \\
(0.48)\end{array}$ & $\begin{array}{c}0.008 \\
(0.42)\end{array}$ & $\begin{array}{c}0.008 \\
(0.44)\end{array}$ & $\begin{array}{l}0.062^{*} \\
(1.73)\end{array}$ & $\begin{array}{l}-0.004 \\
(-0.20)\end{array}$ \\
\hline NetOperatingLoss $_{t-1}$ & + & $\begin{array}{l}-0.025 \\
(-1.28)\end{array}$ & $\begin{array}{l}-0.023 \\
(-1.16)\end{array}$ & $\begin{array}{l}-0.023 \\
(-1.16)\end{array}$ & $\begin{array}{l}-0.042 \\
(-0.91)\end{array}$ & $\begin{array}{l}-0.021 \\
(-1.00)\end{array}$ \\
\hline$\Delta$ CashShortfall $_{t-1}$ & + & $\begin{array}{c}0.015 \\
(0.58)\end{array}$ & $\begin{array}{c}0.014 \\
(0.51)\end{array}$ & $\begin{array}{c}0.015 \\
(0.54)\end{array}$ & $\begin{array}{c}0.054 \\
(0.95)\end{array}$ & $\begin{array}{c}0.002 \\
(0.08)\end{array}$ \\
\hline$\Delta L e v_{t-1}$ & - & $\begin{array}{l}-0.033 \\
(-0.49)\end{array}$ & $\begin{array}{l}-0.041 \\
(-0.63)\end{array}$ & $\begin{array}{l}-0.041 \\
(-0.63)\end{array}$ & $\begin{array}{l}-0.274 * \\
(-1.76)\end{array}$ & $\begin{array}{c}0.049 \\
(0.75)\end{array}$ \\
\hline$\Delta$ Return $_{t-1}$ & \pm & $\begin{array}{l}-0.026 * * * \\
(-3.27)\end{array}$ & $\begin{array}{l}-0.026 * * * \\
(-3.28)\end{array}$ & $\begin{array}{l}-0.025 * * * \\
(-3.26)\end{array}$ & $\begin{array}{l}-0.008 \\
(-0.53)\end{array}$ & $\begin{array}{l}-0.031 * * * \\
(-3.40)\end{array}$ \\
\hline$\Delta$ PastReturn ${ }_{t-1}$ & \pm & $\begin{array}{l}-0.021 \text { *** } \\
(-2.97)\end{array}$ & $\begin{array}{l}-0.021 * * * \\
(-3.03)\end{array}$ & $\begin{array}{l}-0.021 * * * \\
(-3.00)\end{array}$ & $\begin{array}{l}-0.012 \\
(-1.30)\end{array}$ & $\begin{array}{l}-0.024 * * * \\
(-2.68)\end{array}$ \\
\hline$\Delta \sigma$ Return $_{t-1}$ & + & 0.073 & 0.072 & 0.072 & 0.146 & 0.059 \\
\hline
\end{tabular}




\begin{tabular}{|c|c|c|c|c|c|c|}
\hline \multirow{3}{*}{$\Delta R \& D_{t-1}$} & & $(0.99)$ & $(0.98)$ & $(0.97)$ & $(0.82)$ & $(0.73)$ \\
\hline & + & 0.005 & 0.019 & 0.018 & 0.029 & 0.021 \\
\hline & & $(0.08)$ & $(0.34)$ & $(0.32)$ & $(0.20)$ & $(0.38)$ \\
\hline \multirow[t]{2}{*}{$\triangle C A P E X_{t-1}$} & - & 0.002 & -0.000 & -0.003 & 0.011 & 0.014 \\
\hline & & $(0.02)$ & $(-0.00)$ & $(-0.03)$ & $(0.06)$ & $(0.11)$ \\
\hline Year Dummies & & YES & YES & YES & YES & YES \\
\hline Observations & & 11,789 & 11,789 & 11,789 & 2,349 & 9,440 \\
\hline Number of firms & & 1,786 & 1,786 & 1,786 & 1,124 & 1,725 \\
\hline $\mathrm{R}$-square & & 0.1864 & 0.1876 & 0.1880 & 0.1417 & 0.2091 \\
\hline Adjusted R-square & & 0.1843 & 0.1854 & 0.1856 & 0.1302 & 0.2065 \\
\hline
\end{tabular}

$t$-statistics in parentheses $* * * \mathrm{p}<0.01, * * \mathrm{p}<0.05, * \mathrm{p}<0.10$. Year dummies are omitted for brevity. Year dummies are omitted for brevity. The equations have been estimated using a pooled OLS model with robust standard errors. Our key inferences remain after clustering by both firm and year, or using a fixed-effects model. 